\title{
SCIENTIFIC REPORTS

\section{OPEN Process development for scale-up production of a therapeutic L-asparaginase by Streptomyces brollosae NEAE-115 from shake flasks to bioreactor}

\begin{abstract}
Noura El-Ahmady El-Naggar ${ }^{1}{ }^{1}$, Hassan Moawad ${ }^{2}$, Nancy M. El-Shweihy ${ }^{1}$, Sara M. El-Ewasy ${ }^{1}$, Islam A. Elsehemy ${ }^{3}$ \& Nayera A. M. Abdelwahed (iD ${ }^{3}$

L-asparaginase is a promising enzyme that has a wide range of significant applications including cancer therapy and starchy food industries. The statistical design of Plackett-Burman and face centered central composite design were employed to optimize L-asparaginase production by Streptomyces brollosae NEAE-115. As a result, a medium of the following formula is the optimum for producing L-asparaginase in the culture filtrate of Streptomyces brollosae NEAE-115: Dextrose $2 \mathrm{~g}$, starch $20 \mathrm{~g}$, L-asparagine $10 \mathrm{~g}$, $\mathrm{KNO}_{3} 1 \mathrm{~g}, \mathrm{~K}_{2} \mathrm{HPO}_{4} 1 \mathrm{~g}, \mathrm{MgSO}_{4} .7 \mathrm{H}_{2} \mathrm{O} 0.5 \mathrm{~g}, \mathrm{NaCl} 0.1 \mathrm{~g}$, $\mathrm{pH} 7$, fermentation period 7 days, temperature $30^{\circ} \mathrm{C}$, inoculum size $4 \%$, v/v, agitation speed $150 \mathrm{rpm}$ and inoculum age $48 \mathrm{~h}$. The kinetics of cell growth, carbohydrates consumption and L- asparaginase production were studied in 7-L stirred tank bioreactor under different cultivation conditions. A significant increase in both cell growth and carbohydrate consumption was observed as the stirring speed increased from 200 to $600 \mathrm{rpm}$ under uncontrolled pH. The highest L- asparaginase activity of $108.46 \mathrm{U} / \mathrm{mL}$ was obtained after $96 \mathrm{~h}$ at $400 \mathrm{rpm}$. On the other hand, the specific enzyme production $\left(\mathrm{Y}_{\mathrm{p} / \mathrm{x}}\right)$ under uncontrolled $\mathrm{pH}$ reached its maximal value of about $20.3 \mathrm{U} / \mathrm{mg}$ cells. Further improvement of enzyme production was attained by controlling $\mathrm{pH}$ at 7 using the selected stirring speed of $400 \mathrm{rpm}$. Enzyme production of $162.11 \mathrm{U} / \mathrm{mL}$ obtained from the controlled $\mathrm{pH}$ cultures exceeded this value gained from uncontrolled $\mathrm{pH}(108.46 \mathrm{U} / \mathrm{mL})$ by about $50 \%$.
\end{abstract}

L-asparaginase (L-asparagine amino hydrolase, EC3.5.1.1) is an enzyme of high therapeutic value due to its use in certain types of cancer therapy mainly in acute lymphoblastic leukemia (ALL) ${ }^{1}$. It is a tetrameric enzyme that catalyses the hydrolysis of L-asparagine to L-aspartic acid and ammonia ${ }^{2}$. The anti-neoplastic activity of $\mathrm{L}$-asparaginase depends on the fact that neoplastic cells require a large amount of $\mathrm{L}$-asparagine as amino acid to keep up with their rapid malignant growth. The neoplastic cells are deficient in L-asparagine synthetase and are unable to synthesize the needed asparagine-dependent proteins. Therefore, they are dependent on the external sources "consumed in the diet, absorbed in the body and available in the serum" to obtain L-asparagine ${ }^{3}$ for their survival and propagation. Conversely, normal healthy cells are able to synthesize L-asparagine and are therefore protected from L-asparagine-starvation ${ }^{4}$. Therefore, the injection of L-asparaginase intravenously, drastically reduces the level of free L-asparagine in the blood stream and leading to the neoplastic cells are selectively killed due to the absence of L-asparagine ${ }^{5}$. Moreover, L-asparaginase is also used in several industrial fields such as food processing to convert L-asparagine to aspartic acid. Before frying or baking, pretreatment of starchy foods with L-asparaginase reduces acrylamide formation (a carcinogenic toxicant $)^{6}$.

Microbial L-asparaginases have been particularly studied for their applications as a chemotherapeutic agent in the treatment of human cancer ${ }^{7}$. L-asparaginase is produced from a variety of microbial sources including

${ }^{1}$ Department of Bioprocess Development, Genetic Engineering and Biotechnology Research Institute, City for Scientific Research and Technological Applications, Alexandria, Egypt. ${ }^{2}$ Department of Agricultural Microbiology at National Research Center, Cairo, Egypt. ${ }^{3}$ Chemistry of Natural and Microbial Products Dept., Pharmaceutical Industry Division, National Research Centre, 33 El Buhouth St.(Former El Tahrir St.), 12622-Dokki, Giza, Egypt. Correspondence and requests for materials should be addressed to N.E.E. (email: nouraelahmady@yahoo.com) 


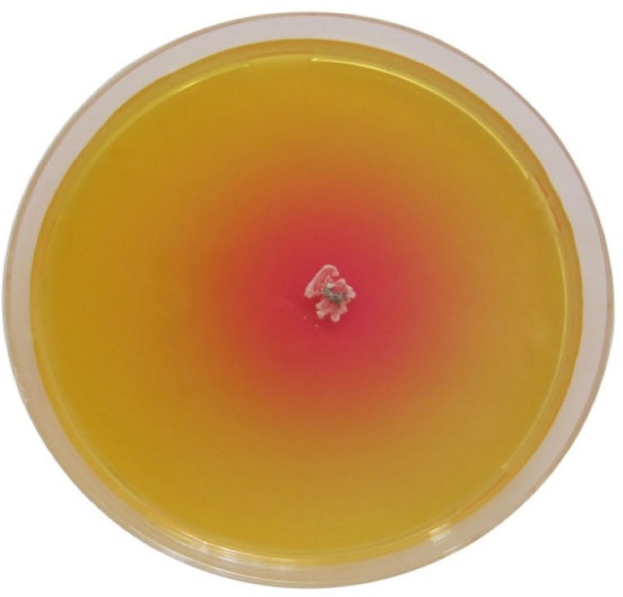

(A)

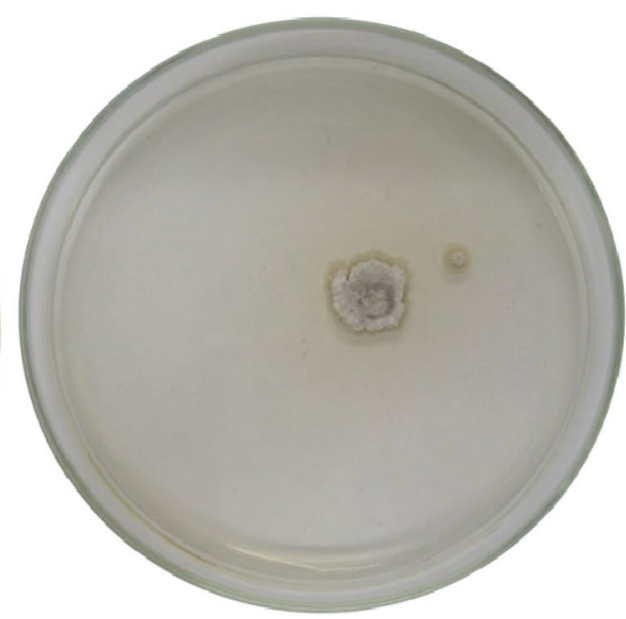

(B)

Figure 1. L-asparaginase activity of Streptomyces brollosae NEAE-115 detected by plate assay (A) production of the enzyme after two days; (B) control plate was prepared without dye.

fungi, yeast, bacteria and actinomycetes by the process of submerged fermentation ${ }^{8}$. Currently, L-asparaginases derived from two bacterial sources, Erwinia chrysanthemi and E. coli, are in clinical use for the treatment of ALL ${ }^{9}$. Few actinomycetes were reported to produce extracellular L-asparaginase, while cell bound L-asparaginase was reported in few actinomycetes like Streptomyces karnatakensis and Streptomyces albidoflavus ${ }^{10}$. Stirred tank bioreactors have been applied for the production of enzymes in large scale batch fermentation ${ }^{11}$.

The aim of the present work targeted the optimization of different process parameters for L-asparaginase production by Streptomyces brollosae NEAE-115 using submerged fermentation in the shake flasks and to optimize the cultivation parameters for large scale production in 7-L stirred tank bioreactor.

\section{Results and Discussion}

Extracellular L-asparaginase production by Streptomyces brollosae NEAE-115 was detected by plate assay method. The color change in the medium from yellow to pink zone surrounding the colony indicated that the organism is a potent producer of L-asparaginase (Fig. 1). In our previous study ${ }^{12}$; L-asparaginase production was performed using submerged fermentation. The enzyme was fractionated by ammonium sulphate precipitation and the purified enzyme was obtained using the ion exchange column of DEAE-Sepharose CL-6B. The purity and molecular weight of the purified enzyme was determined by SDS-PAGE separation, which revealed only one distinctive band with a molecular weight of $67 \mathrm{kDa}$. The purified L-asparaginase was widely active in $\mathrm{pH}$ ranging from 4.5 to 10.5 with maximum activity at $\mathrm{pH} 8.5$. Also, it was widely active at a temperature of 25 to $60^{\circ} \mathrm{C}$ with maximum activity at $37^{\circ} \mathrm{C}$ at incubation time of $50 \mathrm{~min}$ and optimal substrate concentration of $7 \mathrm{mM}$. The enzyme is free of glutaminase activity. Maximum stability of purified L-asparaginase was observed at $40^{\circ} \mathrm{C}$. The enzyme was more stable in alkaline $\mathrm{pH}(\mathrm{pH} 8.5)$ than acidic. In addition, mice treated with Streptomyces brollosae NEAE-115 L-asparaginase inhibited Ehrlich Ascites Carcinoma cells growth in female Swiss albino mice by $79 \%$ with higher cytotoxicity than commercial L-asparaginase. Therefore, in this study, optimization of the various process variables affecting production of L-asparaginase by Streptomyces brollosae NEAE-115 was performed using submerged fermentation in shake flasks and 7-L stirred tank bioreactor.

Evaluation of variables affecting L-asparaginase production by Streptomyces brollosae NEAE-115 using Plackett-Burman design. In order to evaluate the effects of 15 different independent variables and to determine the most significant ones for the maximum production of L-asparaginase, the Plackett-Burman design was applied (Table 1). Dummy variables $\left(D_{1}, D_{2}, D_{3}\right.$ and $\left.D_{4}\right)$ were used to calculate the standard errors of the experiment in data analysis. Table 2 shows the Plackett-Burman design matrix selected to screen the significant variables for L-asparaginase production along with the corresponding experimental and predicted L-asparaginase production. The mycelial growth has developed as large spherical pellets during production of L-asparaginase in shake flasks that can improve the L-asparaginase production than free filament growth (Fig. 2). The variation in L-asparaginase activity shown in various Plackett-Burman design runs was markedly wide $(6.604$ to $79.935 \mathrm{U} / \mathrm{mL})$ and reflected the significance of the optimization process to maximize L-asparaginase production. The maximum L-asparaginase activity $(79.935 \mathrm{U} / \mathrm{mL})$ was achieved in the run number 8 when highest levels of incubation time, inoculum size, agitation speed, L-asparagine and lowest levels of inoculum age, initial $\mathrm{pH}, \mathrm{K}_{2} \mathrm{HPO}_{4}, \mathrm{NaCl}$ were used. While the minimum $\mathrm{L}$-asparaginase activity $(6.604 \mathrm{U} / \mathrm{mL})$ was obtained in the run number 10 when minimal levels of incubation time, inoculum size, agitation speed, L-asparagine and maximal levels of inoculum age, initial $\mathrm{pH}, \mathrm{K}_{2} \mathrm{HPO}_{4}, \mathrm{NaCl}_{\text {were }}$ used.

The relationship between $\mathrm{L}$-asparaginase production and the independent variables is determined by multiple-regression statistical analysis and the analysis of variance (ANOVA) of the experimental design was performed which is shown in Table 3. Table 3 and Fig. 3A show the estimated main effect of each variable on 


\begin{tabular}{|c|c|c|c|}
\hline \multirow[b]{2}{*}{ Code } & \multirow[b]{2}{*}{ Variables } & \multicolumn{2}{|c|}{ Levels } \\
\hline & & -1 & +1 \\
\hline $\mathrm{X}_{1}$ & Temperature $\left({ }^{\circ} \mathrm{C}\right)$ & 30 & 37 \\
\hline $\mathrm{X}_{2}$ & Incubation time (days) & 5 & 7 \\
\hline $\mathrm{X}_{3}$ & Inoculum size $(\%, v / v)$ & 2 & 4 \\
\hline $\mathrm{X}_{4}$ & Inoculum age (h) & 24 & 48 \\
\hline $\mathrm{X}_{5}$ & $\mathrm{pH}$ & 7 & 9 \\
\hline $\mathrm{X}_{6}$ & Agitation speed (rpm/min) & 100 & 150 \\
\hline $\mathrm{X}_{7}$ & Dextrose $(\mathrm{g} / \mathrm{L})$ & 2 & 4 \\
\hline $\mathrm{X}_{8}$ & Starch $(\mathrm{g} / \mathrm{L})$ & 10 & 15 \\
\hline $\mathrm{X}_{9}$ & L-asparagine $(\mathrm{g} / \mathrm{L})$ & 4 & 7 \\
\hline $\mathrm{X}_{10}$ & $\mathrm{KNO}_{3}(\mathrm{~g} / \mathrm{L})$ & 1 & 3 \\
\hline $\mathrm{X}_{11}$ & Yeast extract $(\mathrm{g} / \mathrm{L})$ & 0 & 1 \\
\hline $\mathrm{X}_{12}$ & $\mathrm{~K}_{2} \mathrm{HPO}_{4}(\mathrm{~g} / \mathrm{L})$ & 1 & 2 \\
\hline $\mathrm{X}_{13}$ & $\mathrm{MgSO}_{4} \cdot 7 \mathrm{H}_{2} \mathrm{O}(\mathrm{g} / \mathrm{L})$ & 0.1 & 0.5 \\
\hline $\mathrm{X}_{14}$ & $\mathrm{NaCl}(\mathrm{g} / \mathrm{L})$ & 0.1 & 0.5 \\
\hline $\mathrm{X}_{15}$ & $\mathrm{FeSO}_{4} \cdot 7 \mathrm{H}_{2} \mathrm{O}(\mathrm{g} / \mathrm{L})$ & 0 & 0.01 \\
\hline
\end{tabular}

Table 1. Experimental independent variables at two levels used for the production of L-asparaginase by Streptomyces brollosae NEAE-115 using Plackett-Burman design.

L-asparaginase production. With respect to the main effect (Fig. 3A), we can see that seven variables from the fifteen named L-asparagine, starch, incubation time, inoculum size, $\mathrm{MgSO}_{4} \cdot 7 \mathrm{H}_{2} \mathrm{O}$, agitation speed and inoculum age had positive effect on $\mathrm{L}$-asparaginase production where the other eight variables had negative effect on $\mathrm{L}$-asparaginase production (dextrose, $\mathrm{K}_{2} \mathrm{HPO}_{4}, \mathrm{KNO}_{3}$, yeast extract, $\mathrm{NaCl}, \mathrm{FeSO}_{4} .7 \mathrm{H}_{2} \mathrm{O}$, $\mathrm{pH}$ and temperature). The order of significance of the variables that affect L-asparaginase production is illustrated by the Pareto chart (Fig. 3B).

Significance of each coefficient was determined by $P$-values and student's $t$-test, which are listed in Table 3 . The smaller $P$-value and larger $t$-value means the more significant corresponding coefficient ${ }^{13}$. In the current experiment, variables evidencing $P$-values of less than 0.1 (confidence levels exceeding $90 \%$ ) were considered to have significant effects on the activity of L-asparaginase. The ANOVA of the Plackett-Burman design demonstrated that the model was highly significant as was evident from the Fisher's $F$-test value of 23.55 with a very low probability value $(P$-value $=0.0038)$ (Table 3$)$ implies that the terms are significant.

By neglecting the terms that were insignificant $(P>0.1)$, the first order polynomial equation representing the production of L-asparaginase in terms of independent variables was derived:

$$
\begin{aligned}
\mathbf{Y}_{(L-\text { asparaginase production })=} & 26.50+5.41 \times \text { incubation time }+3.70 \times \text { inoculum size }-7.32 \times \mathrm{pH} \\
& +3.37 \times \text { agitation speed }-3.61 \times \text { dextrose }+4.82 \times \text { starch }+7.60 \times L \\
& - \text { asparagine }-5.06 \times \mathrm{KNO}_{3}-4.56 \times \text { yeast extract }-6.06 \times \mathrm{FeSO}_{4} .7 \mathrm{H}_{2} \mathrm{O}
\end{aligned}
$$

The adequacy of the model fit. The normal probability plot of the residuals is an important graphical method detecting and explaining whether or not a data set is normal or departure from the normality ${ }^{14}$. Figure $4 \mathrm{~A}$ shows residuals were plotted against the expected normal values of the model. The normal probability plot of the residuals shows the points near the diagonal line; so, the residuals are distributed normally. This indicates that the expected L-asparaginase production was well fitted with the experimental results. Figure $4 \mathrm{~B}$ presents the plot of predicted values vs. observed values of the response. Points gathered around the diagonal line indicate a good correlation between the expected and experimental values. Figure $4 \mathrm{C}$ shows the plot of predicted versus the residuals, showing an equal distribution of residuals data above and below the $\mathrm{x}$-axis, supporting the adequacy of the appropriate model.

In a confirmation experiment, to assess the accuracy of Plackett-Burman design, the conditions that are expected to be optimum for maximal production of L-asparaginase were $\mathrm{pH}$, temperature $30^{\circ} \mathrm{C}$, inoculum size $4 \%, \mathrm{v} / \mathrm{v}$, inoculum age $48 \mathrm{~h}$, agitation speed $150 \mathrm{rpm} / \mathrm{min}$, incubation time 7 days and medium of the following composition: g/L (dextrose 2, starch 15, L-asparagine 7, $\mathrm{KNO}_{3} 1, \mathrm{~K}_{2} \mathrm{HPO}_{4} 1, \mathrm{MgSO}_{4} .7 \mathrm{H}_{2} \mathrm{O} 0.5$ and $\mathrm{NaCl}$ 0.1 ). Under these conditions, the maximum L-asparaginase activity was $75.151 \mathrm{U} / \mathrm{mL}$ which is higher than the L-asparaginase activity before applying Plackett Burman design $(20.37 \mathrm{U} / \mathrm{mL})$ by 3.69 times.

Erva et al. ${ }^{15}$ developed a system for optimizing culture conditions and nutritional components in order to enhance the production of extracellular antileukemic L-asparaginase by novel Enterobacter aerogenes KCTC2190/ MTCC111. Traditional one variable at a time method was used to find the key culture conditions and nutritional components and then response surface methodology was implemented to determine their optimal concentrations. An enzyme activity of $18.35 \mathrm{U} / \mathrm{mL}$ was achieved at the optimum process variable values (incubation time was at $40 \mathrm{~h}, \mathrm{pH} 6$, temperature was maintained at $33^{\circ} \mathrm{C}$, substrate concentration was $1.34 \%$, and inoculum size of $2 \%, \mathrm{~V} / \mathrm{V})$. 


\begin{tabular}{|c|c|c|c|c|c|c|c|c|c|c|c|c|c|c|c|c|c|c|c|c|c|c|}
\hline \multirow[b]{2}{*}{ Run } & \multirow[b]{2}{*}{$\mathrm{X}_{1}$} & \multirow[b]{2}{*}{$\mathrm{X}_{2}$} & \multirow[b]{2}{*}{$\mathrm{X}_{3}$} & \multirow[b]{2}{*}{$\mathrm{X}_{4}$} & \multirow[b]{2}{*}{$X_{5}$} & \multirow[b]{2}{*}{$X_{6}$} & \multirow[b]{2}{*}{$\mathrm{X}_{7}$} & \multirow[b]{2}{*}{$\mathbf{X}_{8}$} & \multirow[b]{2}{*}{$\mathrm{X}_{9}$} & \multirow[b]{2}{*}{$X_{10}$} & \multirow[b]{2}{*}{$X_{11}$} & \multirow[b]{2}{*}{$X_{12}$} & \multirow[b]{2}{*}{$\mathbf{X}_{13}$} & \multirow[b]{2}{*}{$\mathrm{X}_{14}$} & \multirow[b]{2}{*}{$\mathbf{X}_{15}$} & \multirow[b]{2}{*}{ Dummy $_{1}$} & \multirow[b]{2}{*}{ Dummy $_{2}$} & \multirow[b]{2}{*}{ Dummy $_{3}$} & \multirow[b]{2}{*}{ Dummy $_{4}$} & \multicolumn{2}{|c|}{$\begin{array}{l}\text { L-asparaginase activity } \\
(\mathrm{U} / \mathrm{mL})\end{array}$} & \multirow[b]{2}{*}{ Residuals } \\
\hline & & & & & & & & & & & & & & & & & & & & \begin{tabular}{|l|} 
Experimental \\
\end{tabular} & Predicted & \\
\hline 1 & 1 & -1 & 1 & -1 & -1 & -1 & -1 & 1 & 1 & -1 & 1 & 1 & -1 & -1 & 1 & 1 & 1 & 1 & -1 & 44.095 & \begin{tabular}{|l|}
47.339 \\
\end{tabular} & -3.244 \\
\hline 2 & -1 & 1 & 1 & -1 & 1 & 1 & -1 & -1 & 1 & 1 & 1 & 1 & -1 & 1 & -1 & 1 & -1 & -1 & -1 & 34.371 & 38.262 & -3.891 \\
\hline 3 & 1 & -1 & -1 & -1 & -1 & 1 & 1 & -1 & 1 & 1 & -1 & -1 & 1 & 1 & 1 & 1 & -1 & 1 & -1 & 21.179 & 22.755 & -1.576 \\
\hline 4 & 1 & 1 & 1 & 1 & -1 & 1 & -1 & 1 & -1 & -1 & -1 & -1 & 1 & 1 & -1 & 1 & 1 & -1 & -1 & 72.033 & 77.592 & -5.559 \\
\hline 5 & 1 & -1 & 1 & -1 & 1 & -1 & -1 & -1 & -1 & 1 & 1 & -1 & 1 & 1 & -1 & -1 & 1 & 1 & 1 & 17.080 & -3.891 & 3.891 \\
\hline 6 & -1 & -1 & -1 & -1 & 1 & 1 & -1 & 1 & 1 & -1 & -1 & 1 & 1 & 1 & 1 & -1 & 1 & -1 & 1 & 40.025 & \begin{tabular}{|l|}
38.449 \\
\end{tabular} & 1.576 \\
\hline 7 & 1 & 1 & -1 & 1 & 1 & -1 & -1 & 1 & 1 & 1 & 1 & -1 & 1 & -1 & 1 & -1 & -1 & -1 & -1 & 25.108 & 24.606 & 0.502 \\
\hline 8 & -1 & 1 & 1 & -1 & -1 & 1 & 1 & 1 & 1 & -1 & 1 & -1 & 1 & -1 & -1 & -1 & -1 & 1 & 1 & 79.935 & 74.376 & 5.559 \\
\hline 9 & 1 & 1 & -1 & 1 & -1 & 1 & -1 & -1 & -1 & -1 & 1 & 1 & -1 & 1 & 1 & -1 & -1 & 1 & 1 & 42.587 & 37.028 & 5.559 \\
\hline 10 & -1 & -1 & -1 & 1 & 1 & -1 & 1 & 1 & -1 & -1 & 1 & 1 & 1 & 1 & -1 & 1 & -1 & 1 & -1 & 6.604 & 8.180 & -1.576 \\
\hline 11 & -1 & -1 & 1 & 1 & -1 & 1 & 1 & \begin{tabular}{|l|}
-1 \\
\end{tabular} & -1 & 1 & 1 & 1 & 1 & -1 & 1 & -1 & 1 & -1 & -1 & 8.198 & 9.365 & -1.166 \\
\hline 12 & 1 & 1 & -1 & -1 & 1 & 1 & 1 & 1 & -1 & 1 & -1 & 1 & -1 & -1 & -1 & -1 & 1 & 1 & -1 & 28.752 & 27.603 & \begin{tabular}{|l|l|}
1.149 \\
\end{tabular} \\
\hline 13 & -1 & -1 & -1 & -1 & -1 & -1 & -1 & -1 & -1 & -1 & -1 & -1 & -1 & -1 & -1 & -1 & -1 & -1 & -1 & 34.331 & 33.829 & 0.502 \\
\hline 14 & -1 & 1 & 1 & 1 & 1 & -1 & 1 & -1 & 1 & -1 & -1 & -1 & -1 & 1 & 1 & -1 & 1 & 1 & -1 & 33.648 & 32.499 & 1.149 \\
\hline 15 & 1 & -1 & -1 & 1 & 1 & 1 & 1 & -1 & 1 & -1 & 1 & -1 & -1 & -1 & -1 & 1 & 1 & -1 & 1 & 22.944 & 25.761 & -2.817 \\
\hline 16 & -1 & 1 & -1 & -1 & -1 & -1 & 1 & 1 & -1 & 1 & 1 & -1 & -1 & 1 & 1 & 1 & 1 & -1 & 1 & 7.515 & 10.332 & -2.817 \\
\hline 17 & -1 & -1 & 1 & 1 & 1 & 1 & -1 & 1 & -1 & 1 & -1 & -1 & -1 & -1 & 1 & 1 & -1 & 1 & 1 & 20.325 & 19.159 & 1.166 \\
\hline 18 & 1 & -1 & 1 & 1 & -1 & -1 & 1 & 1 & 1 & 1 & -1 & 1 & -1 & 1 & -1 & -1 & -1 & -1 & 1 & 51.411 & \begin{tabular}{|l|l|}
48.167 \\
\end{tabular} & 3.244 \\
\hline 19 & 1 & 1 & 1 & -1 & 1 & -1 & 1 & -1 & -1 & -1 & -1 & 1 & 1 & -1 & 1 & 1 & -1 & -1 & 1 & 14.518 & 15.667 & -1.149 \\
\hline 20 & -1 & 1 & -1 & 1 & -1 & -1 & -1 & -1 & 1 & 1 & -1 & 1 & 1 & -1 & -1 & 1 & 1 & 1 & 1 & 56.479 & 56.981 & -0.502 \\
\hline
\end{tabular}

Table 2. Twenty-trial Plackett-Burman experimental design for evaluation of fifteen independent variables with coded values along with the observed L-asparaginase activity. The " -1 " sign correspond to the minimum value and the " +1 " sign correspond to the maximum value of the input parameter range.

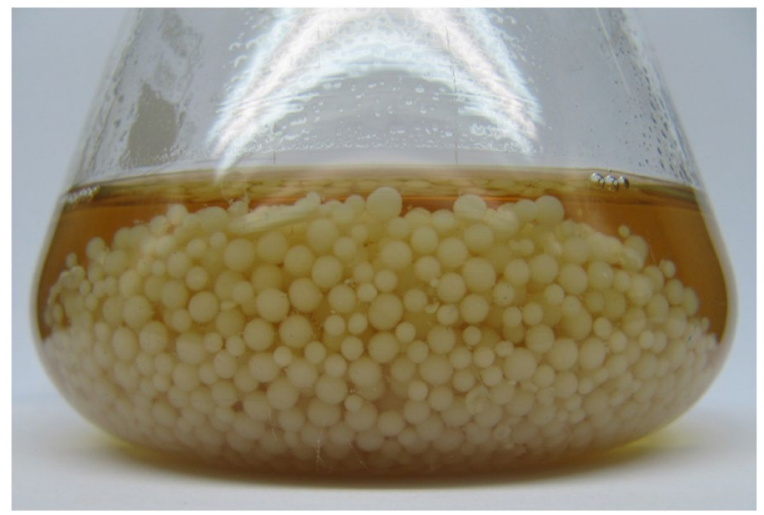

Figure 2. Streptomyces brollosae NEAE-115 growth in large spherical pellets during L-asparaginase production in shake flasks.

Baskar and Renganathan ${ }^{16}$ used the 2-level Plackett-Burman design in 12 experimental run to evaluate the importance of 8 process variables of medium components and operating conditions for the production of L-asparaginase by Aspergillus terreus MTCC 1782. The most important factors significantly influenced L-asparaginase production were L-asparagine, corn flour, urea and potassium chloride. Shakambari et al. ${ }^{17}$ used the Plackett-Burman design involving 12 trials and two levels of concentrations to evaluate the effect of different culture conditions on glutaminase free L-asparaginase production by Pseudomonas plecoglossicida RS1. They reported that, out of seven crucial factors examined, $\mathrm{KH}_{2} \mathrm{PO}_{4}$, sugar cane industry effluent as an alternate substrate to L-asparagine and $\mathrm{pH}$ were the most significant factors and the maximum $\mathrm{L}$-asparaginase production was $3.63 \mathrm{U} \mathrm{mL}^{-1}$ in the optimized medium. As well, Kumar et al. ${ }^{18}$ used the Plackett-Burman design to evaluate the importance of 23 fermentation variables for L-asparaginase production by Streptomyces radiopugnans MS1. The most important variables were Tapioca effluent, corn steep liquor, L-asparagine and aeration. On the other hand, Venil et al. ${ }^{19}$ optimized the medium for production of L-asparaginase by Serratia marcescens SB08. They found that, out of 11 fermentation variables screened by Plackett-Burman design experiments, four variables, sucrose, peptone, $\mathrm{KH}_{2} \mathrm{PO}_{4}$ and incubation time, were the best for production of $\mathrm{L}$-asparaginase. Moreover, Rajamanickam et al. ${ }^{20}$ used 12 runs Plackett-Burman design to screen the influence of eleven factors 


\begin{tabular}{|c|c|c|c|c|c|}
\hline Variables & Coefficients & Main effect & $t$-Stat & $P$-value & Confidence level (\%) \\
\hline Intercept & 26.50 & 53.00 & 29.32 & 0.0000 & 100.00 \\
\hline Temperature $\left({ }^{\circ} \mathrm{C}\right)$ & -0.29 & -0.58 & -0.32 & 0.7655 & 23.45 \\
\hline Incubation time (days) & 5.41 & 10.83 & 5.99 & 0.0039 & 99.61 \\
\hline Inoculum size (\%, v/v) & 3.70 & 7.41 & 4.10 & 0.0149 & 98.51 \\
\hline Inoculum age $(\mathrm{h})$ & 0.78 & 1.56 & 0.86 & 0.4364 & 56.36 \\
\hline $\mathrm{pH}$ & -7.32 & -14.63 & -8.10 & 0.0013 & 99.87 \\
\hline Agitation speed (rpm/min) & 3.37 & 6.73 & 3.72 & 0.0204 & 97.96 \\
\hline Dextrose $(\mathrm{g} / \mathrm{L})$ & -3.61 & -7.21 & -3.99 & 0.0163 & 98.37 \\
\hline Starch $(g / L)$ & 4.82 & 9.64 & 5.33 & 0.0060 & 99.41 \\
\hline L-asparagine $(\mathrm{g} / \mathrm{L})$ & 7.60 & 15.20 & 8.41 & 0.0011 & 99.89 \\
\hline $\mathrm{KNO}_{3}(\mathrm{~g} / \mathrm{L})$ & -5.06 & -10.13 & -5.60 & 0.0050 & 99.50 \\
\hline Yeast extract $(\mathrm{g} / \mathrm{L})$ & -4.56 & -9.12 & -5.05 & 0.0072 & 99.28 \\
\hline $\mathrm{K}_{2} \mathrm{HPO}_{4}(\mathrm{~g} / \mathrm{L})$ & -0.24 & -0.49 & -0.27 & 0.8004 & 19.96 \\
\hline $\mathrm{MgSO}_{4} \cdot 7 \mathrm{H}_{2} \mathrm{O}(\mathrm{g} / \mathrm{L})$ & 0.83 & 1.67 & 0.92 & 0.4091 & 59.09 \\
\hline $\mathrm{NaCl}(\mathrm{g} / \mathrm{L})$ & -1.39 & -2.79 & -1.54 & 0.1980 & 80.20 \\
\hline $\mathrm{FeSO}_{4} \cdot 7 \mathrm{H}_{2} \mathrm{O}(\mathrm{g} / \mathrm{L})$ & -6.06 & -12.13 & -6.71 & 0.0026 & 99.74 \\
\hline \multicolumn{6}{|c|}{ Analysis of variance (ANOVA) } \\
\hline & \begin{tabular}{|l}
$\begin{array}{l}\text { Degree of } \\
\text { freedom }\end{array}$ \\
\end{tabular} & \begin{tabular}{|l|}
$\begin{array}{l}\text { Sum of } \\
\text { squares }\end{array}$ \\
\end{tabular} & $\begin{array}{l}\text { Mean sum } \\
\text { of squares }\end{array}$ & $\begin{array}{l}\text { F- Fisher's } \\
\text { function }\end{array}$ & $\begin{array}{l}\text { Significance F (P- } \\
\text { value) }\end{array}$ \\
\hline Regression & 15 & 5769.95 & 384.66 & 23.55 & 0.0038 \\
\hline Residual & 4 & 65.33 & 16.33 & & \\
\hline Total & 19 & 5835.27 & & & \\
\hline
\end{tabular}

Table 3. Statistical analysis of Plackett-Burman design showing coefficient values, $t$-test, $P$-values and confidence level (\%) for each variable affecting L-asparaginase production by Streptomyces brollosae NEAE- 115 . Multiple R 0.9943, R Square 0.9888, Adjusted R Square 0.9468.
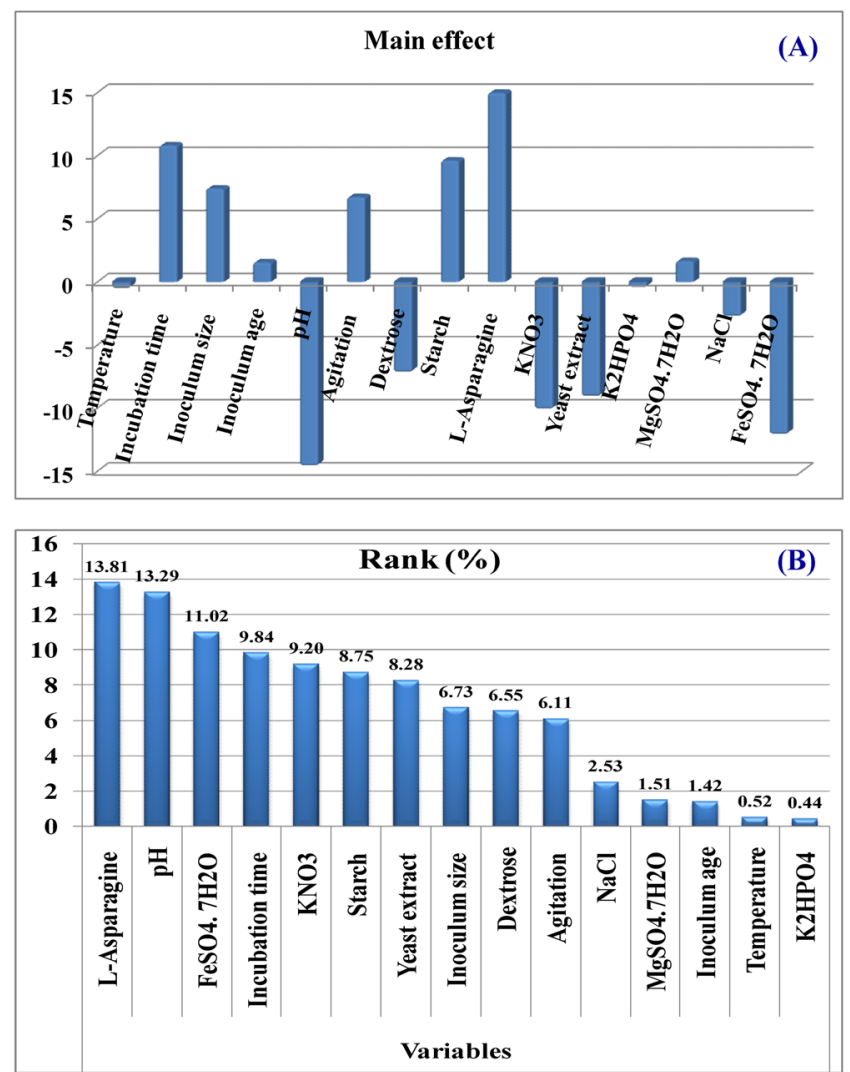

Figure 3. (A) The main effects of different variables on L-asparaginase production according to the PackettBurman experimental results; (B) Pareto chart illustrates the order of significance of each variable. 


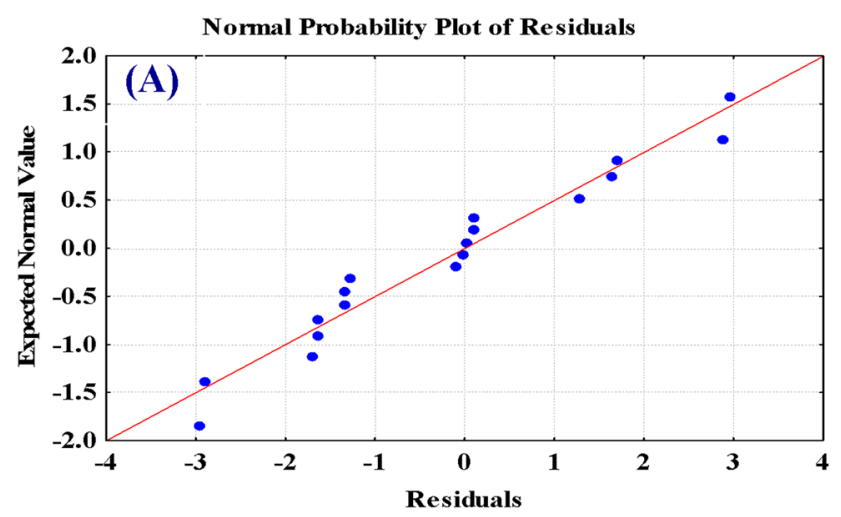

Predicted vs. Observed Values

Dependent variable: L-asparaginase activity $(\mathrm{U} / \mathbf{m L})$

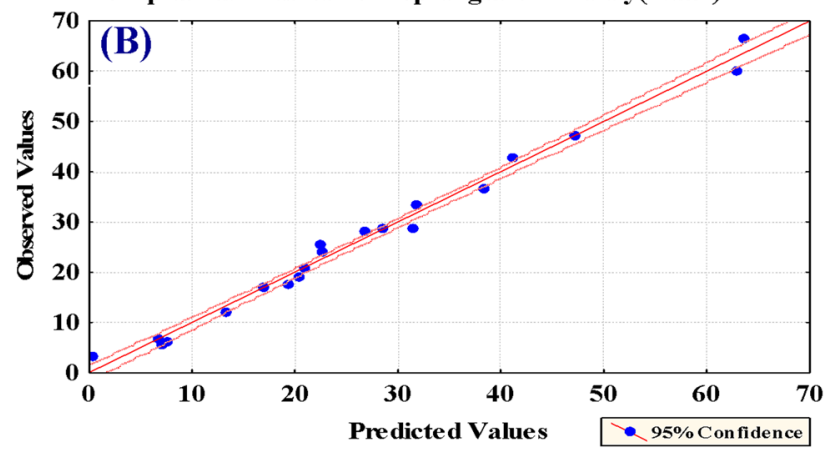

Predicted vs. Residual Scores

Dependent variable: L-asparaginase activity $(\mathrm{U} / \mathbf{m L})$

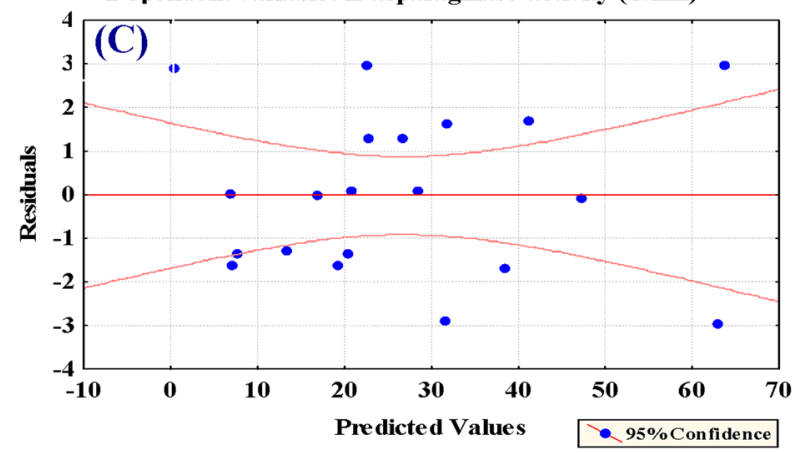

Figure 4. (A) The normal probability plot of residuals for L-asparaginase production as determined by the firstorder polynomial equation, (B) correlation between predicted against observed values and (C) Plot of residuals against predicted values.

on L-asparaginase production by Streptomyces parvulus KUA106. Among the factors screened, four factors with the greatest significance effects were asparagine, tryptone, dextrose and $\mathrm{NaCl}$.

Statistical optimization of L-asparaginase production by Streptomyces brollosae NEAE-115 using face centered central composite design (FCCD). The calculated $t$-values (Table 3 ) revealed that, incubation time $\left(\mathrm{X}_{2}\right)$, starch $\left(\mathrm{X}_{8}\right)$ and L-asparagine $\left(\mathrm{X}_{9}\right)$ were the most significant factors had positive effects on L-asparaginase production by Streptomyces brollosae NEAE-115 and thus were selected for further optimization using FCCD. Other factors in this study were maintained at a constant level giving maximum production of $\mathrm{L}$-asparagine in Plackett-Burman experiments. A total of 20 experiments with different combination of $\mathrm{X}_{2}, \mathrm{X}_{8}$ and $\mathrm{X}_{9}$ were performed and the experimental and predicted L-asparaginase production and residuals are presented in Table 4. The results showed significant variations in production of L-asparaginase. The maximum L-asparaginase activity $(80.39 \mathrm{U} / \mathrm{mL}$ ) was achieved in the center point runs (numbers $9,10,13,14,18$ and 20) when using incubation time of 7 days, $20 \mathrm{~g} / \mathrm{L}$ starch and $10 \mathrm{~g} / \mathrm{L} \mathrm{L}$-asparagine. Whereas, the minimum L-asparaginase activity $(7.52 \mathrm{U} / \mathrm{mL})$ was observed in the run number 12 after 9 days of incubation time when $10 \mathrm{~g} / \mathrm{L}$ starch and $7 \mathrm{~g} / \mathrm{L}$ L-asparagine were used. 


\begin{tabular}{|c|c|c|c|c|c|c|}
\hline \multirow[b]{2}{*}{ Trials } & \multicolumn{3}{|c|}{ Variables } & \multicolumn{2}{|c|}{ L-asparagine activity $(\mathrm{U} / \mathrm{mL})$} & \multirow[t]{2}{*}{ Residuals } \\
\hline & $\mathrm{X}_{2}$ & $\mathrm{X}_{8}$ & $\mathrm{X}_{9}$ & Experimental & Predicted & \\
\hline 1 & 1 & 0 & 0 & 36.05 & 40.71 & -4.66 \\
\hline 2 & 0 & 1 & 0 & 70.16 & 73.08 & -2.92 \\
\hline 3 & 1 & 1 & 1 & 15.97 & 18.43 & -2.47 \\
\hline 4 & 0 & 0 & -1 & 58.93 & 63.43 & -4.49 \\
\hline 5 & 1 & 1 & -1 & 41.69 & 37.87 & 3.81 \\
\hline 6 & 0 & -1 & 0 & 59.62 & 66.48 & -6.87 \\
\hline 7 & -1 & -1 & 1 & 30.14 & 31.51 & -1.37 \\
\hline 8 & -1 & 1 & 1 & 20.15 & 16.03 & 4.13 \\
\hline 9 & 0 & 0 & 0 & 80.39 & 77.13 & 3.26 \\
\hline 10 & 0 & 0 & 0 & 80.39 & 77.13 & 3.26 \\
\hline 11 & -1 & 0 & 0 & 34.27 & 39.40 & -5.12 \\
\hline 12 & 1 & -1 & -1 & 7.52 & 9.20 & -1.68 \\
\hline 13 & 0 & 0 & 0 & 80.39 & \begin{tabular}{|l|l|}
77.13 \\
\end{tabular} & 3.26 \\
\hline 14 & 0 & 0 & 0 & 80.39 & \begin{tabular}{|l|}
77.13 \\
\end{tabular} & 3.26 \\
\hline 15 & -1 & -1 & -1 & 13.89 & 8.98 & 4.92 \\
\hline 16 & 1 & -1 & 1 & 21.24 & 16.24 & 5.00 \\
\hline 17 & 0 & 0 & 1 & 59.68 & \begin{tabular}{|l|}
64.97 \\
\end{tabular} & -5.29 \\
\hline 18 & 0 & 0 & 0 & 80.39 & 77.13 & 3.26 \\
\hline 19 & -1 & 1 & -1 & 17.42 & \begin{tabular}{|l|}
19.97 \\
\end{tabular} & -2.55 \\
\hline 20 & 0 & 0 & 0 & 80.39 & \begin{tabular}{|l|l|}
77.13 \\
\end{tabular} & 3.26 \\
\hline Level & (days) & $(g / L)$ & $(\mathrm{g} / \mathrm{L})$ & & & \\
\hline-1 & 5 & 10 & 7 & & & \\
\hline 0 & 7 & 20 & 10 & & & \\
\hline 1 & 9 & 30 & 15 & & & \\
\hline
\end{tabular}

Table 4. Face-centered central composite design with coded and actual levels of the variables representing $\mathrm{L}$-asparaginase activity as influenced by $\mathrm{X}_{2}$ (incubation time), $\mathrm{X}_{8}$ (starch), $\mathrm{X}_{9}$ (L-asparagine) along with the predicted L-asparaginase activity and residuals.

\begin{tabular}{|c|c|c|c|c|c|}
\hline Variables & Coefficients & Main effect & $t$-student's test & \multicolumn{2}{|l|}{$P$-Value } \\
\hline Intercept & 77.13 & 154.26 & 40.06 & \multicolumn{2}{|l|}{0.0000} \\
\hline $\mathrm{X}_{2}$ & 0.66 & 1.31 & 0.37 & \multicolumn{2}{|l|}{0.7185} \\
\hline $\mathrm{X}_{8}$ & 3.30 & 6.60 & 1.86 & \multicolumn{2}{|l|}{0.0921} \\
\hline $\mathrm{X}_{9}$ & 0.77 & 1.55 & 0.44 & \multicolumn{2}{|l|}{0.6718} \\
\hline $\mathrm{X}_{2} \mathrm{X}_{8}$ & 4.42 & 8.84 & 2.23 & \multicolumn{2}{|l|}{0.0497} \\
\hline $\mathrm{X}_{2} \mathrm{X}_{9}$ & -3.87 & -7.75 & -1.96 & \multicolumn{2}{|l|}{0.0790} \\
\hline $\mathrm{X}_{8} \mathrm{X}_{9}$ & -6.62 & -13.24 & -3.34 & \multicolumn{2}{|l|}{0.0075} \\
\hline $\mathrm{X}_{2} \mathrm{X}_{2}$ & -37.08 & -74.15 & -10.98 & \multicolumn{2}{|l|}{0.0000} \\
\hline $\mathrm{X}_{8} \mathrm{X}_{8}$ & -7.35 & -14.69 & -2.18 & \multicolumn{2}{|l|}{0.0547} \\
\hline $\mathrm{X}_{9} \mathrm{X}_{9}$ & -12.93 & -25.85 & -3.83 & \multicolumn{2}{|l|}{0.0033} \\
\hline \multicolumn{6}{|c|}{ Analysis of variance (ANOVA) } \\
\hline & $\begin{array}{l}\text { Degree of } \\
\text { freedom }\end{array}$ & $\begin{array}{l}\begin{array}{l}\text { Sum of } \\
\text { squares }\end{array} \\
\end{array}$ & $\begin{array}{l}\text { Mean sum of } \\
\text { squares }\end{array}$ & $\begin{array}{l}F \text { - Fisher's } \\
\text { function }\end{array}$ & $\begin{array}{l}\text { Significance F } \\
\text { (P-value) }\end{array}$ \\
\hline Regression & 9 & 13804.60 & 1533.844 & 48.89 & $4.33737 \mathrm{E}-07$ \\
\hline Residual & 10 & 313.73 & 31.37 & & \\
\hline Total & 19 & 14118.32 & & & \\
\hline
\end{tabular}

Table 5. Statistical analysis of face-centered central composite design showing coefficient values, main effect, $t$ test and $P$-values. $\mathrm{X}_{2}$ the coded value of incubation time, $\mathrm{X}_{8}$ the coded value of starch and $\mathrm{X}_{9}$ the coded value of L-asparagine. Multiple R 0.9888, R Square 0.9777, Adjusted R Square 0.957.

Multiple regression analysis and ANOVA. Multiple regression analysis was performed to analyze the data and the results of the analysis are presented in Table 5. Analysis of variance (ANOVA) is required for the quadratic regression model to test its significance and adequacy. The ANOVA (Table 5) demonstrates that the model is highly significant, as is evident from the Fisher's $F$-test (48.89) and a very low probability value (4.33737E-07). The significance of each coefficient was determined by the values of $t$ and $P$ (Table 5). 
In order to evaluate the relationship between $\mathrm{L}$-asparaginase production and incubation time $\left(\mathrm{X}_{2}\right)$, starch $\left(\mathrm{X}_{8}\right)$ and $\mathrm{L}$-asparagine $\left(\mathrm{X}_{9}\right)$ and to calculate the maximum $\mathrm{L}$-asparaginase production corresponding to the optimum levels of these variables, a second-order polynomial model equation was proposed to define the predicted response $(\mathrm{Y})$ in terms of the independent variables $\left(\mathrm{X}_{2}, \mathrm{X}_{8}\right.$ and $\left.\mathrm{X}_{9}\right)$ :

$$
\begin{aligned}
\mathrm{Y}_{(L-\text { asparaginaseproduction })=} & 77.13+0.66 \mathrm{X}_{2}+3.30 \mathrm{X}_{8}+0.77 \mathrm{X}_{9}+4.42 \mathrm{X}_{2} \mathrm{X}_{8}-3.87 \mathrm{X}_{2} \mathrm{X}_{9}-6.62 \mathrm{X}_{8} \mathrm{X}_{9} \\
& -37.08 \mathrm{X}_{2}^{2}-7.35 \mathrm{X}_{8}^{2}-12.93 \mathrm{X}_{9}^{2}
\end{aligned}
$$

where $\mathrm{X}_{2}, \mathrm{X}_{8}$ and $\mathrm{X}_{9}$ are the coded values of incubation time, starch and L-asparagine; respectively.

Three dimensional (3D) plots. The interaction effects and optimal levels of the variables were determined by plotting the three dimensional response surface curves (Fig. 5A-C) when one of the variables is fixed at optimum level and the other two are allowed to vary. Figure 5A represents the L-asparaginase activity as a function of incubation time $\left(\mathrm{X}_{2}\right)$, starch $\left(\mathrm{X}_{8}\right)$ by keeping $\mathrm{L}$-asparagine $\left(\mathrm{X}_{9}\right)$ at optimum value. Results showed that the lower and higher incubation time levels supported relatively low levels of L-asparaginase activity. The highest level of L-asparaginase activity was obtained with intermediate incubation time and starch concentration value. Incubation time has a significant effect on the production of L-asparaginase. The effect of incubation time on $\mathrm{L}$-asparaginase production by Streptomyces acrimycini NGP was studied. Initial production of L-asparaginase on first day was $1.56 \mathrm{U} / \mathrm{mL}$ and increased up to $3.97 \mathrm{U} / \mathrm{mL}$ on $7^{\text {th }}$ day of incubation period ${ }^{21}$. Maximum growth and production of L-asparaginase (ranging from 186.37 to $257.06 \mathrm{U} / \mathrm{mL}$ ) by Serratia marcescens SB08 showed at $51 \mathrm{~h}$ of incubation period and its growth declines in further extended incubation period. Extended incubation time might lead to the enzyme destruction due to interaction with other medium components ${ }^{22}$. L-asparaginase was produced by marine actinomycetes in incubation period of 96 hours $^{23}$. In another report, L-asparaginase activity was increased with time to reach maximum value on the $5^{\text {th }}$ day of incubation ${ }^{24}$. Varalakshmi and Raju ${ }^{25}$ reported that fermentation after 96 hours showed a decrease in L-asparaginase production, which could be attributed to the disruption of the enzyme due to the presence of some kind of proteolytic activity, due to nutrients depletion and accumulation of toxic end products.

Carbon sources are used to promote growth and thus result in an increase in enzyme production, which is usually observed in the synthesis of primary metabolites, such as enzymes ${ }^{26}$. Glucose was considered as a catabolic repressor for L-asparaginase production by certain bacterial strains like E. coli. Synthesis of L- asparaginase in E. coli is almost completely suppressed if glucose is added at a concentration of $0.5 \%$ to the growth medium ${ }^{27}$. In contrast, another literature on L-asparaginase production by Streptomyces spp. reported that glucose followed by starch served as good carbon source for maximal production of L-asparaginase by Streptomyces ginsengisoli ${ }^{10}$. Also, the biosynthesis of L-asparaginase by Streptomyces albidoflavus was high when the strain was cultivated in basal medium with maltose as carbon source followed by starch, glucose, trehalose and glycerol ${ }^{28}$. Bacillus sp. WF $67^{29}$, Serratia marcescens ${ }^{30}$ and Bacillus sp. ${ }^{31}$ preferred glucose as a carbon source to produce L- asparaginase maximally. Dextrose and starch positively affect the production of glutaminase free L-asparaginase by Streptomyces olivaceus NEAE-11932. L-asparagine or the combination of glucose and L-asparagine was found to be the best carbon sources for maximization of L-asparaginase production ${ }^{33}$.

Figure $5 \mathrm{~B}$ represents the L-asparaginase activity as a function of incubation time $\left(\mathrm{X}_{2}\right)$ and L-asparagine $\left(\mathrm{X}_{9}\right)$ by keeping starch $\left(\mathrm{X}_{8}\right)$ at optimum value. L-asparaginase activity was maximized at moderate to high levels of $\mathrm{L}$-asparagine and moderate levels of incubation period, and the increase in incubation period resulted in a gradual decrease in L-asparaginase activity.

Venil and Lakshmanaperumalsamy ${ }^{34}$ reported that the addition of organic nitrogen sources in L-asparagine broth medium was found to induce maximum L- asparaginase production. Whereas, inorganic nitrogen supplements reduce L-asparaginase production significantly. L-asparagine works as a sole source of nitrogen and as inducer for the production of L-asparaginase. Therefore, its differing concentrations will have some effects on enzyme production. The optimum concentration of L-asparagine as a sole nitrogen source was determined to be $1 \%$ for L-asparaginase production by Streptomyces ABR $2^{35}$. L-asparagine was reported to be the best nitrogen source for maximum production of L-asparaginase by Streptomyces venezuelae and Streptomyces karnatakensis ${ }^{36}$. Amena et al. ${ }^{37}$ reported that $0.5 \% \mathrm{~L}$-asparagine proved to be the best nitrogen sources for L-asparaginase production by Streptomyces gulbargensis. Whereas, enhanced L-asparaginase production by Streptomyces albidoflavus was observed by using yeast extract as nitrogen source ${ }^{28}$.

Figure $5 \mathrm{C}$ showes that the maximum L-asparaginase production was attained beyond middle levels of starch $\left(\mathrm{X}_{8}\right)$. Highest value of $\mathrm{L}$-asparaginase production was obtained beyond high $\mathrm{L}$-asparagine concentration $\left(\mathrm{X}_{9}\right)$; lower and higher levels of L-asparagine resulted in a gradual decrease in L-asparaginase production.

Verification of the model. To validate the accuracy of the model and to verify the result, an experiment was conducted under optimal conditions obtained from the face-centered central composite design and compared to the predicted data. The measured L-asparaginase activity obtained was $80.39 \mathrm{U} / \mathrm{mL}$ is close to the predicted one $77.13 \mathrm{U} / \mathrm{mL}$ revealing that a high degree of accuracy $(95.94 \%)$.

Kumar et al. ${ }^{18}$ reported that the optimal levels of the four selected factors for maximum L-asparaginase production $(19.5 \mathrm{U} / \mathrm{mL})$ as obtained from Box-Behnken design were Tapioca effluent, $5 \%$ (v/v); L-asparagine, $0.003 \%$ $(\mathrm{w} / \mathrm{v})$; corn steep liquor, $2 \%(\mathrm{w} / \mathrm{v})$; aeration, $0.7 \mathrm{vvm}$. Meena et al. ${ }^{38}$ used a Box-Behnken design based optimization to investigate the correlation between four variables $(\mathrm{pH}$, starch, yeast extract and L-asparagine) and extracellular L-asparaginase production by marine actinobacteria, Streptomyces griseus NIOT-VKMA29. The optimal values of variables for the highest $\mathrm{L}$-asparaginase production were determined to be: $\mathrm{L}$-asparagine concentration 


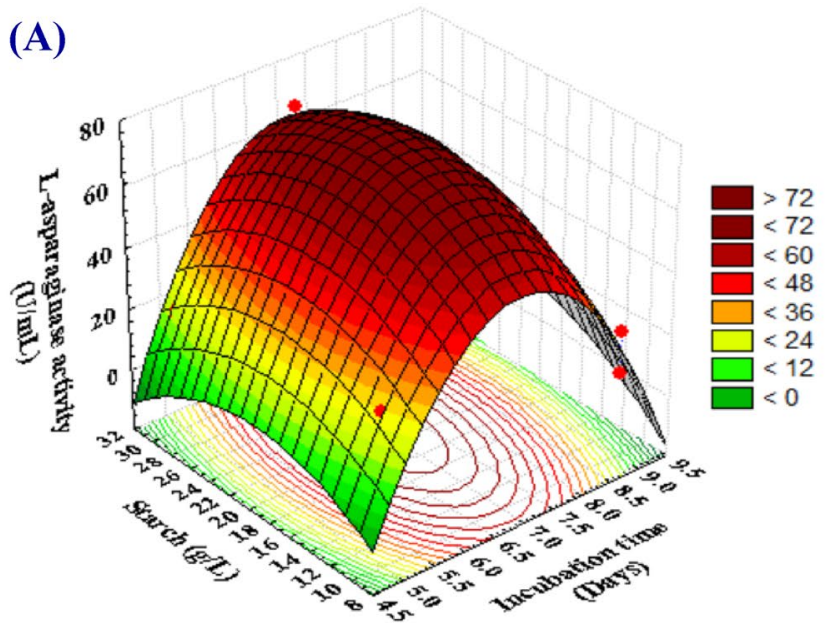

(B)

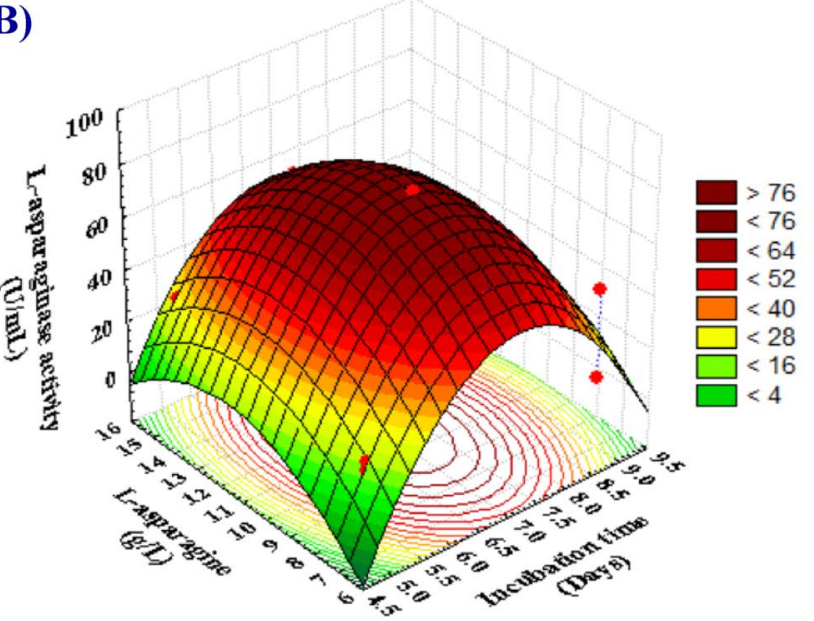

(C)

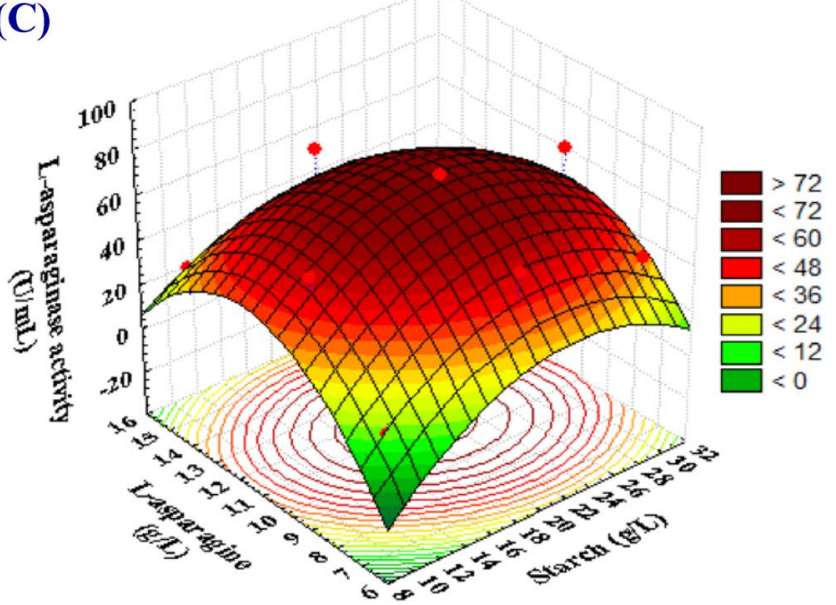

Figure 5. (A-C) Three-dimensional response surface plots showing the effect of incubation time $\left(\mathrm{X}_{2}\right)$, starch $\left(\mathrm{X}_{8}\right)$ and L-asparagine $\left(\mathrm{X}_{9}\right)$ and their interactions effects on the production of L-asparaginase by Streptomyces brollosae NEAE-115.

1.53\%, starch concentration $1.48 \%$, yeast extract concentration $2.04 \%$ and $\mathrm{pH} 8.04$. Box-Behnken guided design of experiments resulted in a maximum L-asparaginase production of $56.50(\mathrm{U} / \mathrm{mL})$.

Shakambari et al. ${ }^{17}$ used central composite design (CCD) to optimize the levels and analyze the combined effect of $\mathrm{KH}_{2} \mathrm{PO}_{4}$, effluent and $\mathrm{pH}$ that were significant for L-asparaginase production by Pseudomonas plecoglossicida using the optimized medium inoculated with $2 \%(\mathrm{v} / \mathrm{v})$ inoculum, incubated at $37^{\circ} \mathrm{C}$ for $48 \mathrm{~h}$ in static conditions. The optimum levels of $\mathrm{KH}_{2} \mathrm{PO}_{4}$, effluent and $\mathrm{pH}$ for the highest L-asparaginase production (3.25 U/ $\mathrm{mL}$ ) were determined to be $\mathrm{KH}_{2} \mathrm{PO}_{4}(0.2 \mathrm{~g} / \mathrm{L})$, effluent $(0.8 \mathrm{~mL})$ and $\mathrm{pH}(6.5)$. RSM guided design of experiments 
resulted in a maximum $\mathrm{L}$-asparaginase production of $3.25 \mathrm{U} / \mathrm{mL}$ with a 4.5 fold increase in enzyme activity compared to that obtained in the unoptimized medium (enzyme activity $0.73 \mathrm{U} / \mathrm{mL}$ ).

Optimization of process variables using central composite design was performed to find out the optimum values of four fermentation variables. The maximum production of $257.55 \mathrm{U} / \mathrm{mL} \mathrm{L}$-asparaginase was achieved under flask conditions using the optimal levels for sucrose, peptone, $\mathrm{KH}_{2} \mathrm{PO}_{4}$ and incubation time were determined as $12.50 \mathrm{~g} / \mathrm{L}, 4.5 \mathrm{~g} / \mathrm{L}, 4.0 \mathrm{~g} / \mathrm{L}$ and $51 \mathrm{~h}^{19}$. Morales-Gonzalez et al..$^{39}$ used central composite design to optimize the levels and to study the effects of nutritional and growth factors that improve L-asparaginase production by Kitasatospora atroaurantiaca, Streptomyces panaciradicis and Streptomyces griseoluteus. The maximum experimental L-asparaginase production by Kitasatospora atroaurantiaca $(28.18 \mathrm{U} / \mathrm{mg}$ protein) was obtained at the optimal levels for lactose concentration $(1 \% \mathrm{w} / \mathrm{v})$, L-asparagine + malt extract concentration $(1 \% \mathrm{w} / \mathrm{v})$, temperature $\left(35^{\circ} \mathrm{C}\right)$ and $\mathrm{pH}(7)$. The maximum experimental L-asparaginase production by Streptomyces panaciradicis $(31.20 \mathrm{U} / \mathrm{mg}$ protein) was achieved at optimal levels of process variables (lactose concentration was $1 \% \mathrm{w} / \mathrm{v}$, $\mathrm{L}$-asparagine + malt extract concentration was $1 \% \mathrm{w} / \mathrm{v}, \mathrm{pH}$ was 7 , temperature was maintained at $35^{\circ} \mathrm{C}$ ). On the other hand, The CCD results for L-asparaginase production by Streptomyces griseoluteus identified the optimal values for lactose, L-asparagine + malt extract concentrations, temperature and $\mathrm{pH}$ were $0.5 \% \mathrm{w} / \mathrm{v}, 0.5 \% \mathrm{w} / \mathrm{v}$, $27.5^{\circ} \mathrm{C}, 6.5$; respectively and the maximum predicted L-asparaginase activity was $30.72 \mathrm{U} / \mathrm{mg}$ protein.

Four factors with the greatest significant effects on L-asparaginase production by Streptomyces parvulus KUA106 were selected for optimization of process using central composite design to find out the optimum levels and to examine the combined effects of these factors. The optimal levels of the four selected factors for maximum L-asparaginase production $(135 \mathrm{U} / \mathrm{mL})$ as obtained using CCD were asparagine $(0.05 \%)$, tryptone $(0.5 \%)$, dextrose $(5 \%)$ and $\mathrm{NaCl}(0.05 \%)^{20}$. Mangamuri et al ${ }^{40}$ used one factor at a time and CCD to evaluate the effect of various physico-chemical factors on L-asparaginase production by Streptomyces labedae VSM-6. Maximum $\mathrm{L}$-asparaginase production $(8.92 \mathrm{U} / \mathrm{mL})$ by Streptomyces labedae VSM-6 using conventional one factor at a time optimization was found after $6^{\text {th }}$ day of incubation in production medium supplemented with $1 \% \mathrm{~L}$-asparagine, $1.5 \%$ starch, $1 \%$ yeast extract at initial $\mathrm{pH} 8$ after $144 \mathrm{~h}$ of incubation. The optimized levels of the nutritional and cultural conditions for maximum L-asparaginase production $(10.17 \mathrm{U} / \mathrm{mL})$ by Streptomyces labedae VSM- 6 were found to be $\mathrm{pH}(8)$, temperature $30^{\circ} \mathrm{C}$, incubation time (6 days), concentrations of yeast extract, starch, and L-asparagine $1,1.5,1 \%$; respectively as determined by using central composite design.

Effect of different stirring speeds on L-asparaginase production under uncontrolled $\mathrm{pH}$ condition. To optimize the stirring speeds in the 7-L stirred tank bioreactor, three stirring speeds of 200, 400 and $600 \mathrm{rpm}$ were adjusted before fermentation in the batch cultivation. The relations between cell growth, enzyme production and substrate consumption as a function of different stirring speeds were studied. As shown in Fig. 6A, the results indicate that the cell growth increased with the time in all cultures until reached a highest value then decreased slightly until the end of the fermentation period. In case of $200 \mathrm{rpm}$, cells grew exponentially for longer time up to $96 \mathrm{~h}$ at a rate $[\mathrm{dx} / \mathrm{dt}]$ of $0.045 \mathrm{~g} / \mathrm{h}^{-1}$ until reached $\left[\mathrm{X}_{\max }\right] 4.3 \mathrm{~g} / \mathrm{L}$. The specific growth rate [in $\mathrm{h}^{-1}$ ] which was calculated based on the exponential part of the growth phase was about $0.0225 \mathrm{~h}^{-1}$. Increasing the stirring speeds to $400 \mathrm{rpm}$ resulted in an increase in cell growth rate recorded $0.067 \mathrm{~g} / \mathrm{h}^{-1}$ until reached maximum value of $5.6 \mathrm{~g} / \mathrm{L}$ at $76 \mathrm{~h}$ with specific growth rate of about $0.0343 \mathrm{~h}^{-1}$ (Table 6). On the other hand, in case of $600 \mathrm{rpm}$ agitated culture, the maximal cell growth $7.2 \mathrm{~g} / \mathrm{L}$ was detected after about $66 \mathrm{~h}$ of cultivation at a rate of $0.0864 \mathrm{~g} / \mathrm{h}^{-1}$ with specific growth rate of about $0.0383 \mathrm{~h}^{-1}$ (Fig. 6A). It was clearly observed that the specific growth rate increased with increasing the stirring speed. On the other hand, the time of the active growth of cells was shortened. During the exponential growth of cells in all cultures, carbohydrates were consumed gradually until depletion when maximum cell growth was recorded (Fig. 6B). In $200 \mathrm{rpm}$ stirring speed, consumption rate of carbohydrates [Qs] was $0.1 \mathrm{~g} / \mathrm{h}^{-1}$ which is less than consumption rate of carbohydrates at 400 and $600 \mathrm{rpm}(0.13$ and $0.141 \mathrm{~g} / \mathrm{h}^{-1}$; respectively).

In culture under $200 \mathrm{rpm}$ stirring speed, enzyme production rate [Qp] of about $0.431 \mathrm{U} / \mathrm{mL} / \mathrm{h}$ was observed during $80 \mathrm{~h}$ of cultivation after which a degradation in this rate with time by $0.366 \mathrm{U} / \mathrm{mL} / \mathrm{h}$ until the end of the fermentation time was recorded. However, a longer production phase of the enzyme in $400 \mathrm{rpm}$ reaching its highest value at $104 \mathrm{~h}$ with a production rate of $1.1 \mathrm{U} / \mathrm{mL} / \mathrm{h}$, after this time a decrease in enzyme production until $120 \mathrm{~h}$ as cells entered a stationary phase was detected. Despite the highest biomass in fermentation culture under higher stirring speed $600 \mathrm{rpm}$ compared to 200 and $400 \mathrm{rpm}$, a moderate L-asparaginase amount attained its highest value of $\left[\mathrm{P}_{\max }\right] 89.7 \mathrm{U} / \mathrm{mL}$ at about $90 \mathrm{~h}$ (Fig. $6 \mathrm{C}$ ) with a production rate of $0.98 \mathrm{U} / \mathrm{mL} / \mathrm{h}$ which was calculated at the beginning of fermentation period. It was observed that maximal specific activity of the enzyme 157.9 (U/mg protein) at $112 \mathrm{~h}$ was recorded in culture of $400 \mathrm{rpm}$ compared to other speed under study (Fig. 6D).

The data also revealed differences between the depletion in the dissolved oxygen which was significant at $200 \mathrm{rpm}$. During first $16 \mathrm{~h}$ of the course of fermentation, a fast and gradual decline of the DO\% level was observed from $100 \%$ at the starting to $1.2 \%$ till reached $0 \%$ at $24 \mathrm{~h}$ whereas a reduction to $4 \%$ after $60 \mathrm{~h}$ at $400 \mathrm{rpm}$ was noticed. In contrast, the depletion was insignificant at higher agitation rate $(600 \mathrm{rpm})$. In all fermentation cultures under study, during the growth phase, the DO\% decreased and reached a minimal value and then increased gradually thereafter as a function of the cell-growth termination when the carbohydrates were completely consumed (Fig. 6B,E).

It was also noticed that the $\mathrm{pH}$ of all cultures increased gradually after inoculation parallel to L-asparaginase production, reached its highest value of 8.3 at $120 \mathrm{~h}$ in case of stirring speed $200 \mathrm{rpm}$ and 9 in case of 400 and $600 \mathrm{rpm}$ at $112 \mathrm{~h}$ and $104 \mathrm{~h}$; respectively (Fig. 6F). Since L-asparaginase converts L-asparagine to L-aspartic acid and ammonia which shifts the $\mathrm{pH}$ towards alkaline and the enzyme as noticed through the results obtained from stirred tank bioreactor at different stirring effect was growth linked and increasing the stirring speeds from 200 to 600 resulted in an increase in cell growth rate. On the other hand, the time of the active growth of cells was shortened. As it was reported before that maximum biomass production could also be correlated with high levels 

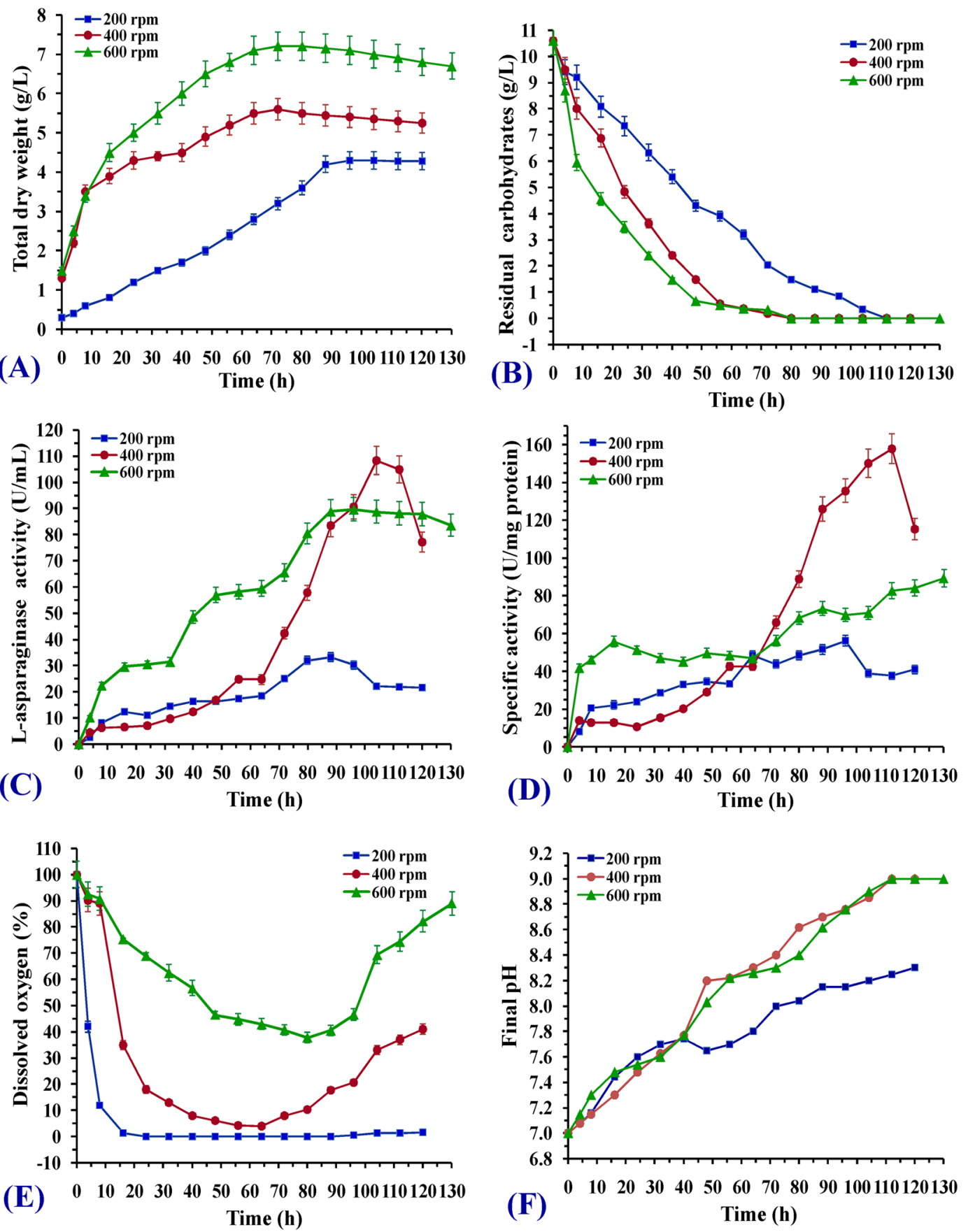

Figure 6. Time-course profile of (A) cell growth; (B) carbohydrates consumption; (C) L-asparaginase production; (D) specific activity; (E) dissolved oxygen and (F) final pH during batch cultivation of Streptomyces brollosae NEAE-115 in 7 L stirred tank bioreactor under different stirring speeds and uncontrolled $\mathrm{pH}$.

of L-asparaginase production. L-asparaginase formation showed a firm link to the active cell growth (Savitri et $a l.)^{5}$, so, at $200 \mathrm{rpm}$ the time of active cell growth was longer than in higher speed, production of the enzyme was slower and conversion of all the $\mathrm{L}$-asparagine in the medium was delayed and alkaline $\mathrm{pH}$ due to ammonia was weak contrary to the other higher stirring speeds.

To clarify the cell performance toward L-asparaginase production in all cultures, the yield coefficients including $\mathrm{Y}_{\mathrm{p} / \mathrm{x}}$ (L-asparaginase produced/biomass of cells produced), $\mathrm{Y}_{\mathrm{p} / \mathrm{s}}$ (L-asparaginase produced/mass of carbohydrates consumed) and $\mathrm{Y}_{\mathrm{x} / \mathrm{s}}$ (biomass of cells produced/mass of carbohydrates consumed) were also calculated (Fig. 7). It was observed that the maximal value of the production yield coefficient $Y_{p / x} 20.3 \mathrm{U} / \mathrm{mg}$ cells was in case of stirring speed 400 whereas lower values of $\mathrm{Y}_{\mathrm{p} / \mathrm{x}}(12.63 \mathrm{U} / \mathrm{mg}$ and $7.93 \mathrm{U} / \mathrm{mg})$ were obtained at 600 and $200 \mathrm{rpm}$ respectively. On the other hand, the highest $\mathrm{Y}_{\mathrm{p} / \mathrm{s}}$ of $10.23 \mathrm{U} / \mathrm{mg}$ carbohydrates value was obtained in case of $400 \mathrm{rpm}$ followed by 3.5 and $8.46 \mathrm{U} / \mathrm{mg}$ carbohydrates in case of 200 and $600 \mathrm{rpm}$. These results indicated that in batch cultivation at $400 \mathrm{rpm}$ the produced cells were more active towards enzyme production as the production 


\begin{tabular}{|l|l|l|}
\hline Kinetic Parameters & \multicolumn{2}{|l|}{ Stirring speed, 400 } \\
\hline $\begin{array}{l}\text { Streptomyces brollosae } \\
\text { NEAE-115 growth }\end{array}$ & Uncontrolled $\mathbf{p H}$ & Controlled $\mathbf{p H}$ \\
\hline $\mathrm{X}_{\text {max-biomass }}(\mathrm{g} / \mathrm{L})$ & 5.6 & 7.78 \\
\hline $\mathrm{X}_{\text {max-time }}(\mathrm{h})$ & 76 & 76 \\
\hline $\mathrm{dx} / \mathrm{dt}\left(\mathrm{g} / \mathrm{h}^{-1}\right)$ & 0.067 & 0.0855 \\
\hline$\mu\left(\mathrm{h}^{-1}\right)$ & 0.0343 & 0.0316 \\
\hline $\mathrm{L}-$ asparaginase production & \multicolumn{2}{|l|}{} \\
\hline $\mathrm{P}_{\text {max-vol }}(\mathrm{U} / \mathrm{mL})$ & 108.46 & 162.11 \\
\hline $\mathrm{P}_{\text {max-time }}(\mathrm{h})$ & 104 & 82 \\
\hline $\mathrm{Q}_{\mathrm{p}}(\mathrm{U} / \mathrm{mL} / \mathrm{h})$ & 1.1 & 1.99 \\
\hline $\mathrm{Y}_{\mathrm{p} / \mathrm{x}}(\mathrm{U} / \mathrm{mg}$ cells $)$ & 20.3 & 21 \\
\hline $\begin{array}{l}\text { Specific activity }(\mathrm{U} / \mathrm{mg} \\
\text { protein })\end{array}$ & 157.9 & 220.6 \\
\hline Carbohydrates utilization & \multicolumn{2}{|l|}{} \\
\hline $\mathrm{Q}_{\mathrm{s}}(\mathrm{g} / \mathrm{L} / \mathrm{h})$ & -0.1324 & -0.16 \\
\hline $\mathrm{Y}_{\mathrm{x} / \mathrm{s}}(\mathrm{g}$ cells/g) & 0.54 & 0.73 \\
\hline $\mathrm{Y}_{\mathrm{p} / \mathrm{s}}(\mathrm{U} / \mathrm{g}$ cells $)$ & 10.23 & 15.3 \\
\hline
\end{tabular}

Table 6. Kinetic parameters for cell growth, L-asparaginase production, carbohydrates consumption during Streptomyces brollosae NEAE-115 growth in 7-L stirred tank bioreactor under stirring speed of $400 \mathrm{rpm}$. " $\mathrm{X}_{\text {max-biomass, }}$ maximal cell dry weight; $\mathrm{dx} / \mathrm{dt}$, cell growth rate; $\mathrm{P}_{\text {max-vol }}$ maximal $\mathrm{L}$-asparaginase production; $\mathrm{P}_{\text {max-time }}$, time of maximal L-asparaginase production; $\mathrm{Q}_{\mathrm{p}}$, L-asparaginase production rate; $\mathrm{Y}_{\mathrm{p} / \mathrm{x}}$, coefficient production yield over biomass; $\mathrm{Q}_{\mathrm{s}}$, carbohydrates consumption rate; $\mathrm{Y}_{\mathrm{x} / \mathrm{s}}$ coefficient biomass yield over substrate; $\mathrm{Y}_{\mathrm{p} / \mathrm{s}}$, coefficient production yield over substrate".

yield coefficient was the highest compared to cultures under stirring at 200 and $600 \mathrm{rpm}$. Calculated coefficient biomass yield over substrate $\mathrm{Y}_{\mathrm{x} / \mathrm{s}}$ was the highest at the stirring speed of $600 \mathrm{rpm}$, i.e. $0.7 \mathrm{~g}$ biomass produced per $\mathrm{g}$ carbohydrates which was depleted after $66 \mathrm{~h}$ of cultivation whereas 0.54 and $0.44 \mathrm{~g}$ biomass produced per $\mathrm{g}$ carbohydrates were recorded in 400 and $200 \mathrm{rpm}$; respectively accompanied by carbohydrates depletion after 76 and $112 \mathrm{~h}$. From these results, the enzyme activity at $400 \mathrm{rpm}$ was the highest and obtained later by almost $8 \mathrm{~h}$ compared to the other speeds. Besides, the production yield coefficient was the highest hence, a stirring speed of $400 \mathrm{rpm}$ is chosen as the optimal one for maximum biosynthesis of L-asparaginase.

One of the important factors that can affect microbial productions in scale-up is the agitation which influence directly on oxygen transfer rate in different scales. In this context, the effect of stirring speed and $\mathrm{pH}$ control on cell growth, L-asparaginase production and other parameter such as DO\% was determined during the course of the submerged fermentation in batch cultivation of the producer microorganism Streptomyces brollosae NEAE-115 in 7-L stirred tank bioreactor. Due to the scarce specific literature available, comparison of our results with those of other scientists is difficult. The low cell biomass and enzyme activity at lower stirring speed $(200 \mathrm{rpm})$ could be attributed to the shortage of oxygen being experienced by the organism due to the insufficient mixing. This agree with the results obtained by Priya et al. ${ }^{41}$, who reported that a positive correlation between L-asparaginase production by Streptomyces sp. (TA22) and cell mass over a time period of 24-120hours. The microorganism at $600 \mathrm{rpm}$ grew faster and got sheared more easily led to the access of maximum cell biomass earlier; at the same time it enhances shearing of cells which badly affect enzyme synthesis. In addition, the shear forces could partially inactivate the enzyme, already released in the cultural broth. In this study, low enzyme activity at low stirring speed at $200 \mathrm{rpm}$ and stirring speed at $600 \mathrm{rpm}$ could be related to catalytic dysfunctions due to conformational changes carried out by mechanical forces $^{42}$. It was observed that as the stirring speed increased, cell biomass increased too because more oxygen was incorporated into the medium and lead to progressive accompanied by an acceleration of carbohydrates consumption. Once carbohydrates were depleted in the culture, a significant decrease in cell dry weight was observed. This reduction was a function of cell lysis under the combined effect of carbohydrates limitation and shear stress effect in the culture ${ }^{43}$. L-asparaginase production was higher in $400 \mathrm{rpm}$ batch culture than in 200 stirring speed, this may be attributed to the dispersion of macromolecules in the medium and increase amount of dissolved oxygen. It might, therefore, contribute to the greater growth and extracellular protein value. A correlation between agitation speed and enzyme production has been reported by researches who worked on Streptomyces gulbargensis ${ }^{44}$. Results also showed that during all batch cultivations, cell growth is associated with large increase in oxygen uptake. In this study, during the active growth phase, the DO\% in culture at $200 \mathrm{rpm}$ dropped significantly after $24 \mathrm{~h}$. In previous studies, it has been reported that DO\% was gradually increased until the end of cultivation time when the cells entered the stationary phase ${ }^{45}$. On the other hand, during the fermentation time, it was noticed that $\mathrm{pH}$ of the medium increased gradually from the beginning of the fermentation time parallel to L-asparaginase production in all batch cultures reached 9 at higher agitation speed and 8.5 at $200 \mathrm{rpm}$.

Batch cultivation for L-asparaginase production under controlled pH. The kinetic data of cell growth, carbohydrates consumption, enzyme activity and DO\% during batch cultivation with a controlled $\mathrm{pH} 7$ at $400 \mathrm{rpm}$ was presented in Table 6 and Figs 8, 9. During the growth phase, cells grew exponentially with rate higher than in batch fermentation at 200 and $400 \mathrm{rpm}$ under uncontrolled $\mathrm{pH}$ and almost the same as $600 \mathrm{rpm}$ while the specific growth rate 


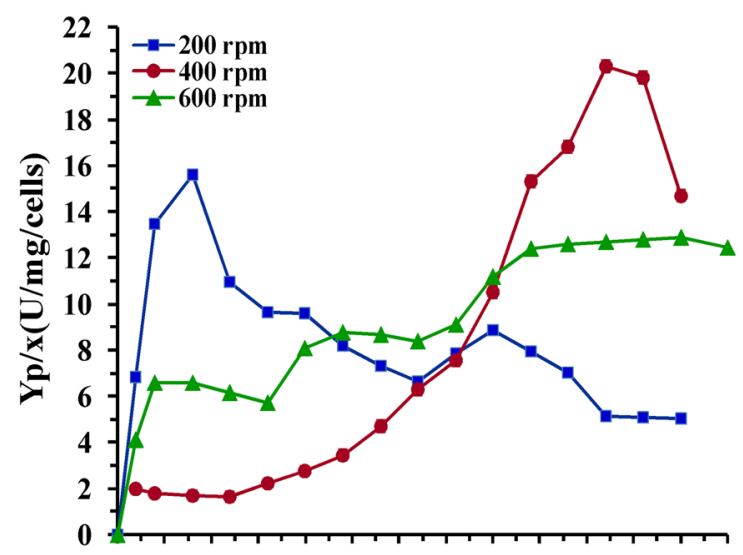

(A)

$\begin{array}{llllllllllll}0 & 10 & 20 & 30 & 40 & 50 & 60 & 70 & 80 & 90 & 100110120130\end{array}$ Time (h)
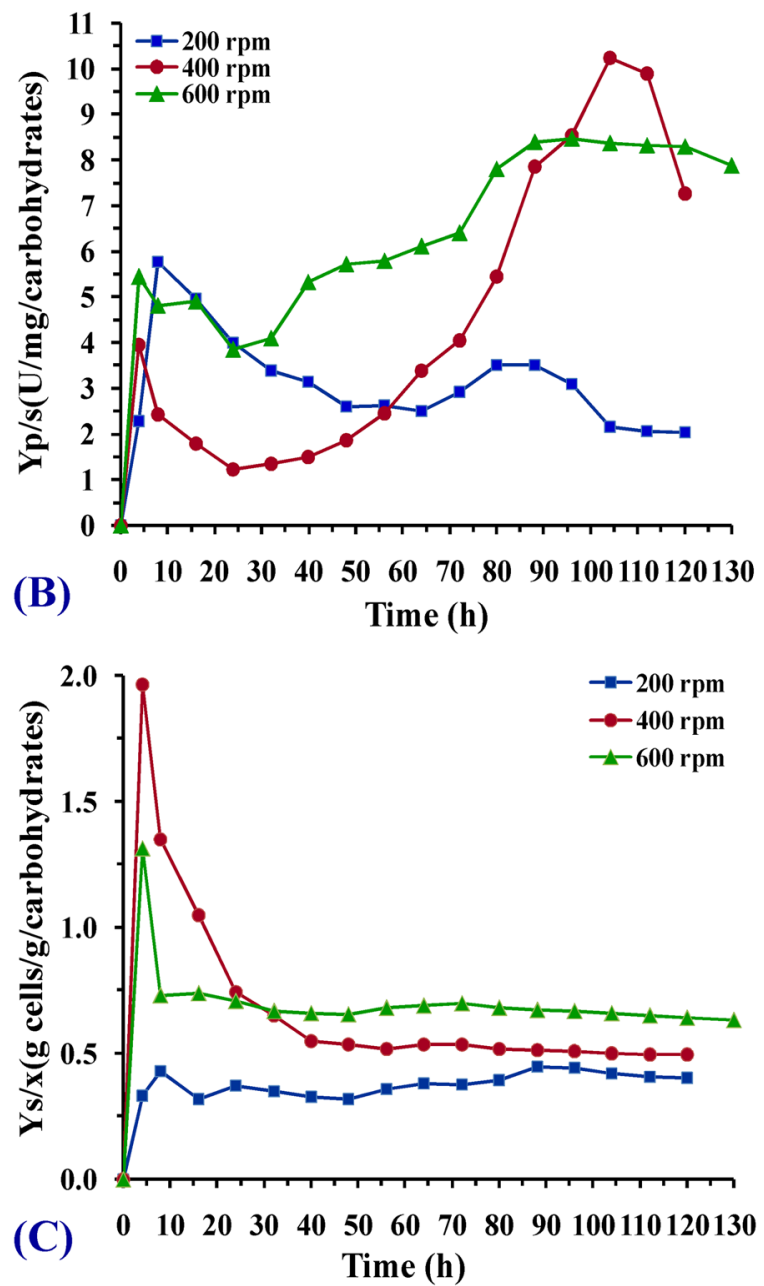

Figure 7. Time profile of yield coefficients: (A) (Yp/x) unit of L-asparaginase per mg biomass; (B) (Yp/s) unit of $\mathrm{L}$-asparaginase per $\mathrm{mg}$ carbohydrates; $(\mathrm{C})(\mathrm{Yx} / \mathrm{s}) \mathrm{g}$ cells per g carbohydrates in batch cultivation under different stirring speeds in 7-L stirred tank bioreactor.

was $0.0316 \mathrm{~h}^{-1}$ and the cell biomass reached its highest value of $7.78 \mathrm{~g} / \mathrm{L}$ at $76 \mathrm{~h}$ (Table 6 ). On the other hand, carbohydrates were consumed at a rate of $0.16 \mathrm{~g} / \mathrm{L} / \mathrm{h}$. L-asparaginase production started from the first hours of fermentation time with a production rate of $1.99 \mathrm{U} / \mathrm{mL} / \mathrm{h}$ and recorded its maximal activity of $162.11 \mathrm{U} / \mathrm{mL}$ at $82 \mathrm{~h}$ then a decrease in production was detected by a degradation rate of $3.3 \mathrm{U} / \mathrm{mL} / \mathrm{h}$ until the end of fermentation time. Whereas, dissolved oxygen level falls rapidly when cell grows enter in the exponential phase. To clarify the difference in growth and production kinetics between cultures at $400 \mathrm{rpm}$ in case of uncontrolled and controlled $\mathrm{pH}$, kinetic parameters related to cell growth and enzyme activity were compared (Table 6). 

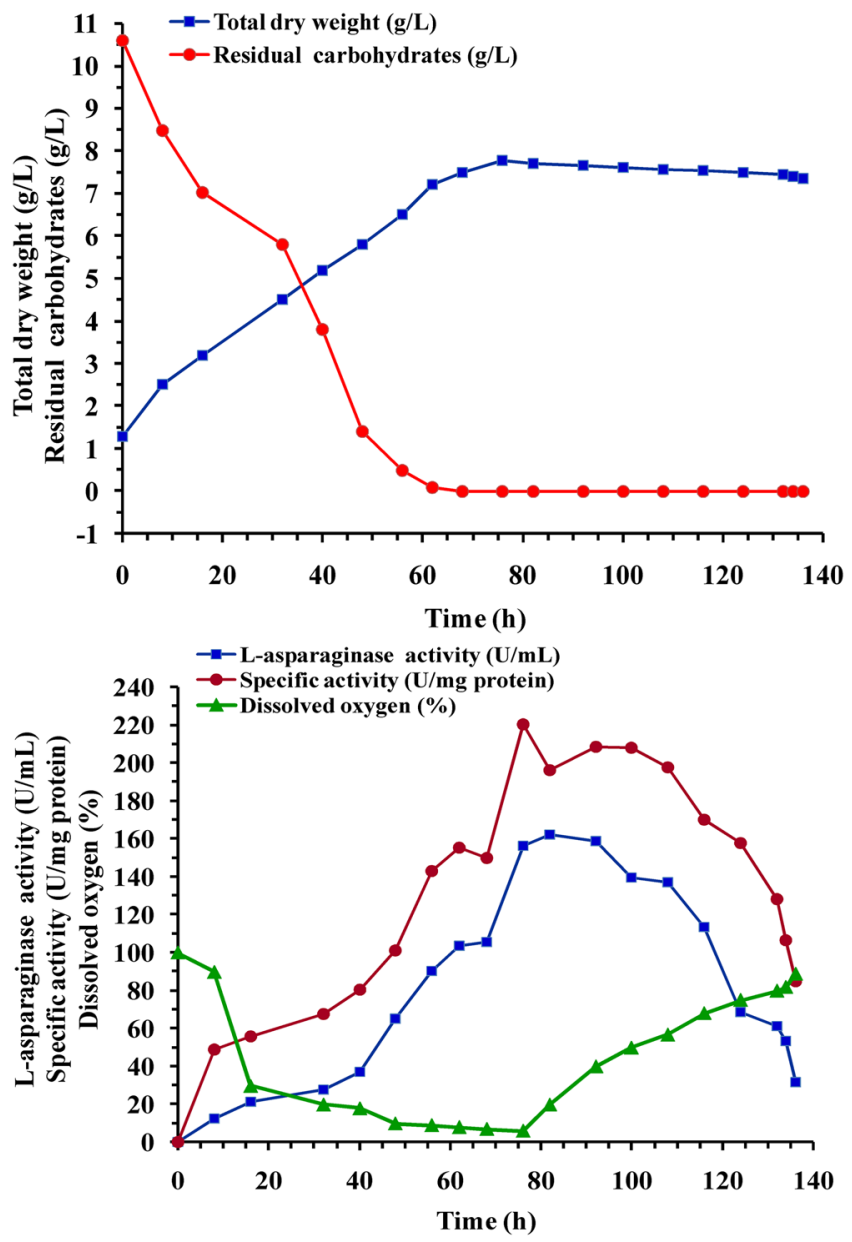

Figure 8. Time-course profile of cell growth; L-asparaginase production; carbohydrates consumption; specific activity and dissolved oxygen during batch cultivation of Streptomyces brollosae NEAE-115 in 7-L stirred tank bioreactor at stirring speed of $400 \mathrm{rpm}$ and controlled $\mathrm{pH} 7$.

The presented data of cells cultivation under uncontrolled and controlled $\mathrm{pH}$ condition revealed that in both cultures, the dissolved oxygen levels were started with $100 \%$ and reached its minimum percentage at $76 \mathrm{~h}$ parallel to maximum cell growth. It is apparent that, cell grew exponentially in both cultivations in which there was no lag phase with different rates. However, controlled $\mathrm{pH}$ condition was more favorable for L-asparaginase and cell mass production than uncontrolled $\mathrm{pH}$ bioreactor. These differences in growth rate and cells yield are linked to the rate of carbohydrates consumption, which also reflects the cell physiology status activity.

When controlling the $\mathrm{pH}$ at 7 during cultivation, the cell mass increased about 1.4-fold when compared with that from the uncontrolled bioreactor cultures. The specific growth rate $[\mu]$ for the controlled bioreactor culture was also higher. A maximum L-asparaginase production $(162.11 \mathrm{U} / \mathrm{mL})$ by Streptomyces brollosae NEAE-115 was reached in $\mathrm{pH}$ controlled culture at $400 \mathrm{rpm}$ which is not reported for any other actinomycete strain so far.

\section{Materials and Methods}

Microorganism and cultivation conditions. The new isolate previously isolated and identified as Streptomyces brollosae NEAE- $115^{46}$ is a potent L-asparaginase-producing strain; cultured and maintained on plates containing starch nitrate agar medium; the inoculated plates were incubated at $30^{\circ} \mathrm{C}$ for 7 days ${ }^{12}$.

Detection of L-asparaginase production by plate assay. Detection of the potential production of L-asparaginase by Streptomyces brollosae NEAE-115 was performed according to the method of El-Naggar et al. ${ }^{12}$ with the use of asparagine dextrose salts agar (ADS agar) medium ${ }^{47}$.

Inoculum preparation for submerged fermentation in shake flasks. Inoculums for submerged fermentation in shake flasks were prepared according to the procedure used by El-Naggar et al. ${ }^{12}$.

L-asparaginase production by Streptomyces brollosae NEAE-115 using submerged fermentation in shake flasks. Streptomyces brollosae NEAE-115 was cultured in $250 \mathrm{~mL}$ Erlenmeyer conical flasks containing fifty $\mathrm{mL}$ of asparagine dextrose salts broth medium (at a specified $\mathrm{pH}$ ). The inoculated flasks were incubated at $30-37^{\circ} \mathrm{C}$ with shaking at $100-150 \mathrm{rpm}$ on a rotatory shaker incubator. After the specified incubation 

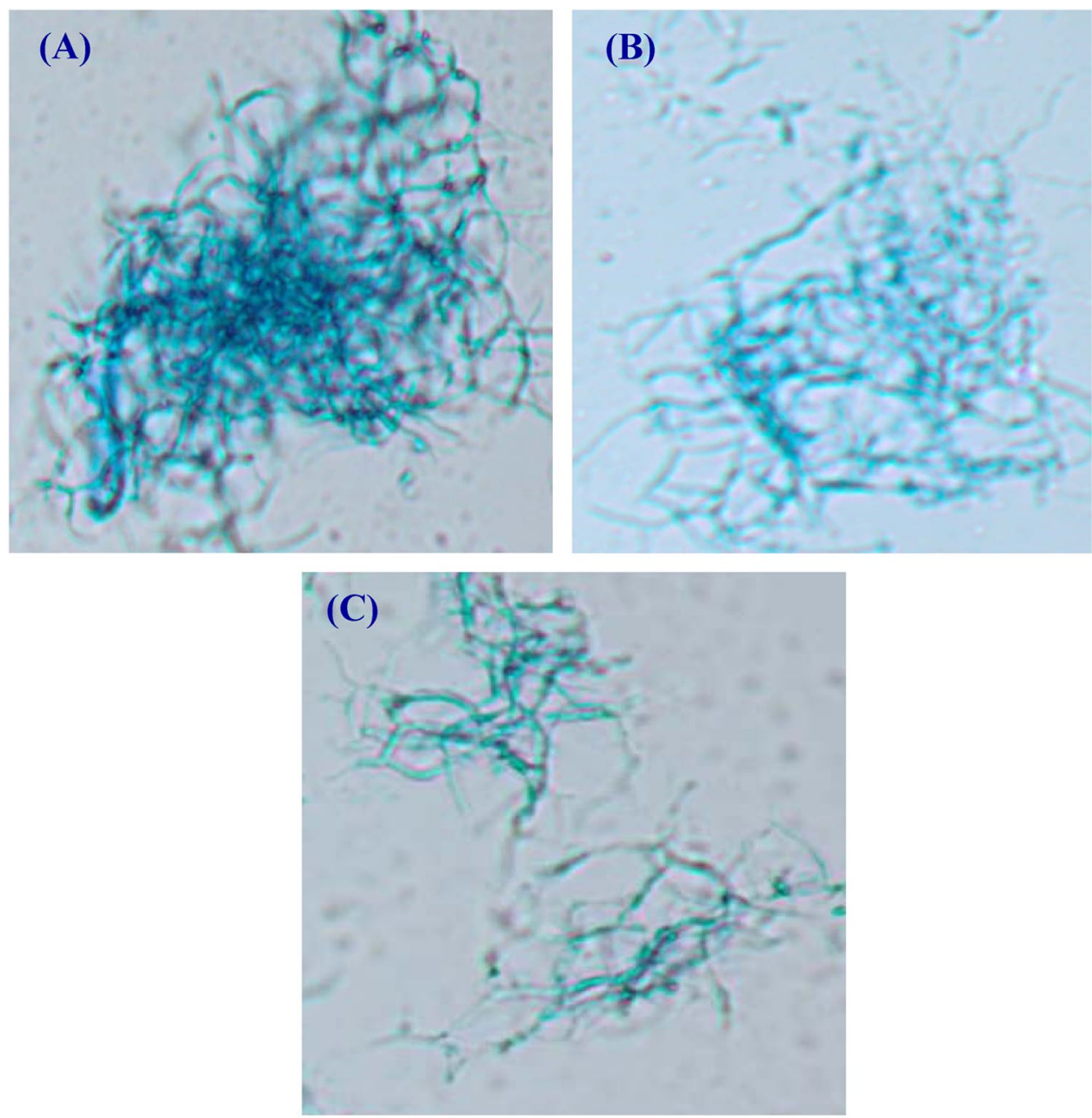

Figure 9. Microscopic observation of Streptomyces brollosae NEAE-115 cells at (A) early fermentation time showing mycelia clump, (B) dispersed mycelia at middle fermentation time and (C) freely dispersed mycelia and spores at late fermentation time of batch cultivations in 7-L stirred tank bioreactor.

period for each set of experimental trials, the mycelial growth of Streptomyces brollosae NEAE-115 was collected using cooling Centrifuge for $20 \mathrm{~min}$ at $5000 \times g$ and $4^{\circ} \mathrm{C}$.

Impact of some carbon sources on L-asparaginase production. A preliminary study was conducted to determine the impact of some carbon sources on L-asparaginase production by Streptomyces brollosae NEAE115. Asparagine dextrose salt broth ${ }^{47}$ supplemented with different carbon sources such as dextrose, maltose, starch, sucrose and glycerol was used.

Assay of L-asparaginase activity. The activity of L-asparaginase was determined by the direct nesslerization method by measuring the quantity of released ammonia ${ }^{48}$. The reaction mixture containing $0.5 \mathrm{~mL}$ of L-asparaginase and $1.5 \mathrm{~mL}$ of $0.04 \mathrm{M} \mathrm{L}$-asparagine (prepared in $0.05 \mathrm{M}$ Tris- $\mathrm{HCl}$ buffer, $\mathrm{pH}$ 8.6). The reaction mixture tubes were incubated in a water bath shaker at $37^{\circ} \mathrm{C}$ for 30 minutes. $0.5 \mathrm{~mL}$ of $1.5 \mathrm{M}$ Trichloroacetic acid (TCA) was used to stop the reaction. The blank was prepared by adding the enzyme after addition of TCA, one blank has been conducted for each sample tested. By centrifugation at $10,000 \times g$ for $10 \mathrm{~min}$, the precipitated proteins were separated. The released ammonia in the supernatant was colorimetrically determined by direct nesslerization by adding $1 \mathrm{~mL}$ of Nessler's reagent to tubes containing $0.5 \mathrm{~mL}$ of clear supernatant diluted with $7 \mathrm{~mL}$ of distilled water and incubated at room temperature for $20 \mathrm{~min}$. The yellow color formation indicates the presence of ammonia and was measured with UV-visible spectrophotometer (Optizen Pop-UV/Vis spectrophotometer) at $480 \mathrm{~nm}$. The quantity of ammonia released was calculated using the standard curve of ammonium chloride. One unit (U) of L-asparaginase is defined as the amount of L-asparaginase that has catalyzed the formation of $1 \mu$ mole of ammonia from $\mathrm{L}$-asparagine per minute under the standard assay conditions. The activity of the enzyme has been expressed as units per gram of dry fermented substrate (U/gds).

Selection of significant variables influencing L-asparaginase production by Plackett-Burman design. The Plackett-Burman statistical experimental design ${ }^{49}$ is a two factorial design, which identifies different process variables that had a significant effect, either positively or negatively on L-asparaginase production during 
submerged fermentation in shake flasks with respect to their main effects ${ }^{50}$. Different process variables influencing L-asparaginase production by Streptomyces NEAE-115 were identified using Plackett-Burman experimental design. Total of fifteen variables (assigned) (dextrose, starch, $\mathrm{L}$-asparagine, $\mathrm{KNO}_{3}$, yeast extract, $\mathrm{K}_{2} \mathrm{HPO}_{4}, \mathrm{MgSO}_{4} .7 \mathrm{H}_{2} \mathrm{O}, \mathrm{NaCl}$ and $\mathrm{FeSO}_{4} \cdot 7 \mathrm{H}_{2} \mathrm{O}, \mathrm{pH}$, incubation time, temperature, inoculum age, inoculum size and agitation speed) (Table 1) and four dummy (unassigned) variables were selected for this study in 20 trials (Table 2). Each variable is represented at high $(+)$ and low $(-)$ levels. The design of the Plackett-Burman depends on the first order model:

$$
Y=\beta_{0}+\sum \beta_{i} X_{i}
$$

where, $\mathrm{Y}$ is the predicted L-asparaginase production, $\mathrm{X}_{\mathrm{i}}$ is independent variable level, $\beta_{\mathrm{i}}$ is the linear coefficient and $\beta_{0}$ is the model intercept. All runs were conducted in duplicate and the average of L-asparaginase activity was used as responses.

Optimization of L-asparaginase production using face centered central composite design (FCCD). The FCCD was used to determine the optimal levels of the three most significant positive independent variables affecting the production of the enzyme (incubation time, starch and L-asparagine) and to study the individual and mutual interactions among the tested variables on L-asparaginase production. The FCCD is a statistical experimental design in which each variable is varies on three different levels, low $(-1)$, medium $(0)$, high $(+1)$ and the center point was repeated six times, resulting in a total of 20 runs. Given all linear, quadratic and interaction coefficients, the regression model can be illustrated using the following second-degree polynomial equation:

$$
Y=\beta_{0}+\sum_{i} \beta_{i} X_{i}+\sum_{i i} \beta_{i i} X_{i}+\sum_{i j} \beta_{i j} X_{j}
$$

In which $Y$ is the predicted response, $\beta_{0}$ is the regression coefficients, $\beta_{\mathrm{i}}$ is the linear coefficient, $\beta_{\mathrm{ii}}$ is the quadratic coefficients, $\beta_{\mathrm{ij}}$ is the interaction coefficients), and $\mathrm{X}_{\mathrm{i}}$ is the coded level of independent variable.

Statistical analysis. The obtained experimental results were subjected to multiple regression analysis using Microsoft Excel, 2007 and the STATISTICA software "Version 8.0, StatSoft Inc., Tulsa, USA" was used to plot the three-dimensional surface plots.

Inoculum preparation for 7-L stirred tank bioreactor. A first-stage seed culture was grown by inoculating a $250 \mathrm{~mL}$ shake flask $(50 \mathrm{~mL}$ working volume) containing production medium composed of $(\mathrm{g} / \mathrm{L})$ : (dextrose 1 , soluble starch $5, \mathrm{KNO}_{3} 1$, yeast extract $1, \mathrm{~K}_{2} \mathrm{HPO}_{4} 2, \mathrm{MgSO}_{4} .7 \mathrm{H}_{2} \mathrm{O} 0.5, \mathrm{NaCl} 0.5$ and $\mathrm{FeSO}_{4} .7 \mathrm{H}_{2} \mathrm{O} 0.01$ with a single vial of frozen stock culture. The flask was incubated at $30^{\circ} \mathrm{C}$ in a temperature controlled shaking incubator operating at $150 \mathrm{rpm}$ for $48 \mathrm{~h}$. A second stage of seed growth is required to prepares the microorganism for enzyme production. From the first-stage culture $5 \%(\mathrm{v} / \mathrm{v})$ inoculum was transferred to a 1-L shake flask ( $250 \mathrm{~mL}$ working volume) containing the previously mentioned production medium, then incubated at $30^{\circ} \mathrm{C}$ and $150 \mathrm{rpm}$ for $48 \mathrm{~h}$.

Submerged fermentation using 7-L stirred tank bioreactor. Batch fermentations were inoculated by transferring around $10 \%(\mathrm{v} / \mathrm{v})$ of the second stage flask culture directly to the 7-L stirred tank bioreactor (bioflow 310; New Brunswick Scientific, Edison, NJ, U.S.A.) containing the previously mentioned production medium $(\mathrm{pH} 7)$. The useful volume used in the fermentations was 5-L. The bioreactor is equipped with digitally controlled $\mathrm{pH}$ electrode, temperature probe, polarographic DO electrode "Ingold, Mittler-Toledo, Switzerland) and two six-blade Rushton turbine impellers ( $5.2 \mathrm{~cm}$ diameter)", fixed on the agitator shaft above $3.2 \mathrm{~cm}$ air sparger. The $\mathrm{pH}$ electrode was calibrated by using standard buffers (Fluka) at $\mathrm{pH} 7$ and 9 prior to the sterilization of bioreactor $\left(121^{\circ} \mathrm{C}\right.$ for $\left.20 \mathrm{~min}\right)$. However, the calibration of $\mathrm{DO}$ electrode was conducted after sterilization by the air until $100 \%$ saturation was achieved. The foam was manually controlled by adding a few drops of silicon -based antifoam (Sigma) at foam time.

The temperature in the $7-\mathrm{L}$ vessel was controlled at $30^{\circ} \mathrm{C}$. The airflow rate was set at $(0.5 \mathrm{vvm})$ using filtered sterile air and stirring speed was allowed by varying the stirring speed rate in the bioreactor $(200,400$ and $600 \mathrm{rpm}$ ) for the comparison between different stirring speeds on the enzyme production without $\mathrm{pH}$ control. The suitability of the stirring speed was determined on the basis of the results obtained. The enzyme production was then studied by controlling the $\mathrm{pH}$ of the culture at 7.0 with sodium hydroxide $2 \mathrm{M}$ or $2 \mathrm{M}$ hydrochloric acid during the whole fermentation process.

Sample preparation and determination of cells dry weight. $10 \mathrm{~mL}$ of broth samples were collected at different time's intervals during the fermentation process in pre-weighed, $15 \mathrm{~mL}$ sterile falcon tubes and centrifuged at $1865 \mathrm{RCF}$ for $15 \mathrm{~min}$. A small fraction of the supernatant was frozen at $-20^{\circ} \mathrm{C}$ for carbohydrates, protein and L-asparaginase activity determinations. Whereas, the pellets containing cell debris were washed twice with distilled water, centrifuged and then the washed pellets were dried to constant weight at $70^{\circ} \mathrm{C}$ for determination of cells dry weight.

Estimation of total protein. Total protein in culture filtrate was determined using bovine serum albumin as standard according to the method of Lowry et al. ${ }^{51}$.

Estimation of total carbohydrates. The total carbohydrates were determined spectrophotometrically according to the method of Dubois et al. ${ }^{52}$. 


\section{Conclusion}

As a conclusion, maximum L-asparaginase production can be achieved at $400 \mathrm{rpm}$ under controlled $\mathrm{pH}$ at 7 . The fundamental results obtained in this research are beneficial for further development of Streptomyces brollosae NEAE-115 cultivation strategy for the overproduction on a pilot scale.

\section{References}

1. Kumar, K. \& Verma, N. The various sources and application of L-asparaginase. Asian J Biochem Pharm Res 2, 197-205 (2012).

2. Sanghvi, G. et al. Mitigation of acrylamide by L-asparaginase from Bacillus subtilis KDPS1 and analysis of degradation products by HPLC and HPTLC. Springer Plus 5, 533 (2016).

3. Keating, M. J., Holmes, R., Lerner, S. \& Ho, D. H. L-asparaginase and PEG asparaginase-past, present, and future. Leukemia \& lymphoma 10, 153-157 (1993).

4. Duval, M. et al. Comparison of Escherichia coli-asparaginase with Erwinia-asparaginase in the treatment of childhood lymphoid malignancies: results of a randomized european organisation for research and treatment of cancer-children's leukemia group phase 3 trial. Blood 99, 2734-2739 (2002).

5. Savitri, A. N. \& Azmi, W. Microbial L-asparaginase: A potent antitumour enzyme. Ind J Biotechnol 2, 184-194 (2003).

6. Pedreschi, F., Kaack, K. \& Granby, K. The effect of asparaginase on acrylamide formation in French fries. Food chem. 109, 386-392 (2008).

7. El-Naggar, N. E., Deraz, S., Soliman, H. M. \& El-Ewasy, S.M. Purification and characterization of L-asparaginase, a therapeutic protein, from the newly isolated alkaliphilic Streptomyces fradiae. Scientific Reports 6, Article number: 32926 (2016).

8. Kumar, D. S. \& Sobba, K. L-asparaginase from microbes: a comprehensive review. Adv Biores 3, 137-157 (2013).

9. Salzer, W. L., Asselin, B. L., Plourde, P. V., Corn, T. \& Hunger, S. P. Development of asparaginase Erwinia chrysanthemi for the treatment of acute lymphoblastic leukemia. Ann N Y Acad Sci 1329, 81-98 (2014).

10. Deshpande, N., Choubey, P. \& Agashe, M. Studies on optimization of growth parameters for L-asparaginase production by Streptomyces ginsengisoli. The Sci World J (2014).

11. Prasad, R., Abraham, Tk \& Nair, A. J. Scale up of production in a bioreactor of a halotolerant protease from moderately halophilic Bacillus sp. isolated from soil. Braz Arch Biol Technol 57, 448-455 (2014).

12. El-Naggar, N. E., Deraz, F. S., El-Ewasy, S. M. \& Suddek, G. M. Purification, characterization and immunogenicity assessment of glutaminase free L-asparaginase from Streptomyces brollosae NEAE-115. BMC Pharmacol Toxicol 19, 51 (2018).

13. Akhnazarova, S. \& Kafarov, V. Experiment Optimization in Chemistry and Chemical Engineering. Mir Publishers, Moscow (1982).

14. Montgomery, D. Experiments with a single factor: the analysis of variance. Design and analysis of experiments 7, 87-89 (1991).

15. Erva, R. R., Goswami, A. N., Suman, P., Vedanabhatla, R. \& Rajulapati, S. B. Optimization of L-asparaginase production from novel Enterobacter sp., by submerged fermentation using response surface methodology. Prep Biochem Biotechnol 47(3), 219-228 (2016).

16. Baskar, G. \& Ranganathan, S. Statistical screening of process variables for the production of L-asparaginase from cornflour by Aspergillus terreus MTCC 1782 in submerged fermentation. Indian J Sci Technol 2(5), 0974-6846 (2009).

17. Shakambari, G., Sumi, B. M., Ashokkumar, B., Peramachi, P. \& Perumal, V. Industrial effluent as a substrate for glutaminase free. L-asparaginase production from Pseudomonas plecoglossicida strain RS1; media optimization, enzyme purification and its characterization. RSC Adv 5, 48729-48738 (2015).

18. Kumar, M. S. \& Selvam, K. \& Singaravel. Statistical assessment of medium components by factorial design and surface methodology of L-asparaginase production by isolated Streptomyces radiopugnans MS1 in submerged fermentation using Tapioca Effluent. Asian J Appl Sci 5, 252-265 (2012).

19. Venil, C. K., Nanthakumar, K., Karthikeyan, K. \& Lakshmanaperumalsamy, P. Production of L-asparaginase by Serratia marcescens SB08: Optimization by response surface methodology. Iranian J Biotechnol 7, 10-18 (2009).

20. Rajamanickam, U., Mala, K. K., Venil, C. K. \& Palaniswamy, M. Screening of actinomycetes from mangrove ecosystem for L-asparaginase activity and optimization by response surface methodology. Polish J Microbiol 60, 213-221 (2011).

21. Selvam, K. \& Vishnupriya, B. Partial purification and cytotoxic activity of L-asparaginase from Streptomyces acrimycini NGP. Int $J$ Res Pharma Biomed 4, 859-69 (2013).

22. Ramesh, M. V. \& Lonsane, B. K. Solid-state fermentation for production of amylase by Bacillus megaterium 16M. Biotechnol Lett 51, 323-328 (1987).

23. Senthilkumar, M. \& Selvam, K. Isolataion and purification of high efficiency L-asparaginase by quantitative preparative continuouselution SDS-PAGE electrophoresis. Microbial Biochem Technol 3, 73-83 (2011).

24. Thirunavukkarasu, N., Suryanarayanan, T. S., Murali, T. S., Ravis-hankar, J. P. \& Gummadi, S. N. L-asparaginase from marine derived fungal endophytes of sea weeds. Mycosphere 2, 147-155 (2011).

25. Varalakshmi, V. \& Raju, J. K. Optimization of L - asparaginase production by Aspergillus terreus MTCC 1782 using Bajra seed flour under solid state fermentation. Int J Res Eng Technol 2, 121-129 (2013).

26. Chen, X. C. et al. Medium optimization for the production of cyclic adenosine $3^{\prime}, 5^{\prime}$-monophosphate by Microbacterium sp. no. 205 using response surface methodology. Bioresource technol 100, 919-924 (2009).

27. Garaev, M. M. \& Golub, E. I. Mechanism of the effect of glucose on L- asparaginase synthesis by Escherichia coli bacteria. Mikrobiologiya 46, 433-439 (1977).

28. Narayana, K., Kumar, K. \& Vijayalakshmi, M. L-asparaginase production by Streptomyces albidoflavus. Ind J Microbiol 48, 331-336 (2008).

29. Ahmad, S. S., Abdel-Fattah, M., Othman, A. M. \& Saad, W. F. L-asparaginase production by a thermotolerant Bacillus sp. WF67: Nutritional and cultural parameters optimization. Bioscie Res 15(2), 1390-1400 (2018).

30. Sukumaran, C. P., Singh, D. V. \& Mahadevan, P. R. Synthesis of L-asparaginase by Serratia marcescens (Nima). J Biosci 1, 263-269 (1979).

31. Moorthy, V., Ramalingam, A., Sumantha, A. \& Shankaranaya, R. T. Production, purification and characterisation of extracellular L-asparaginase from a soil isolate of Bacillus sp. Afr J Microbiol Res 4, 1862-1867 (2010).

32. El-Naggar, N. E., Moawad, H., El-Shweihy, N. M. \& El-Ewasy, S. M. Optimization of culture conditions for production of the antileukemic glutaminase free L-asparaginase by newly isolated Streptomyces olivaceus NEAE-119 using response surface methodology. BioMed Res Int (2015).

33. Kumar, S., Dasu, V. V. \& Pakshirajan, K. Localization and production of novel L-asparaginase from Pectobacterium carotovorum MTCC 1428. Process Biochemistry 45, 223-229 (2010).

34. Venil, C. \& Lakshmanaperumalsamy, P. Solid state fermentation for production of L-asparaginase in rice bran by Serratia marcescens SB08. Inter J Microbiol 7(1), 30 (2008).

35. Sudhir, A. P., Dave, B. R., Trivedi, K. A. \& Subramanian, R. B. Production and amplification of an L-asparaginase gene from actinomycete isolate Streptomyces ABR2. Ann microbial 62, 1609-1614 (2012).

36. Mostafa, S. Activity of L-asparaginase in cells of Streptomyces karnatakensis. Zentralbl Bakteriol Parasitenkd Infektionskr Hyg 134, 343-351 (1979).

37. Amena, S., Vishalakshi, N., Prabhakar, M., Dayanand, A. \& Lingappa, K. Production, purification and characterization of L-asparaginase from Streptomyces gulbargensis. Braz j Microbiol 41, 173-178 (2010). 
38. Meena, B., Anburajan, L., Sathish, T., Raghavan, R. V. \& Dharani, G. L-asparaginase from Streptomyces griseus NIOT-VKMA29: optimization of process variables using factorial designs and molecular characterization of L-asparaginase gene. Sci rep 5, 12404 (2015).

39. Morales-Gonzalez, M., Martinez, B. S., Rodriguez, L., Gómez, J. E. C. \& Diaz, L. E. Optimization of L-asparaginase activity of Actinobacteria isolated from Guaviare river sediments in Colombia. Tropical J Pharmaceut Res 17(11), 2199-2206 (2018).

40. Mangamuri, U., Vijayalakshmi, M., Ganduri, V. S. R. K., Babu, S. \& Poda, R. S. Extracellular L-asparaginase from Streptomyces labedae VSM-6: Isolation, production and optimization of culture conditions using RSM. Pharmacog J. 9(6), 931-40 (2017).

41. Priya, P. M., Radhakrishnan, M. \& Balagurunathan, R. Production and optimization of L-asparaginase from Streptomyces sp (TA22) isolated from Western Ghats, India. J Chem Pharm Res 3, 618-624 (2011).

42. Fenice, M., Barghini, P., Selbmann, L. \& Federici, F. Combined effects of agitation and aeration on the chitinolytic enzymes production by the Antarctic fungus Lecanicillium muscarium CCFEE 5003. Microb Cell Fac 11 (2012).

43. Elsayed, E. A. O., Hoda, G. \& El-Enshasy, H. A. Development of Fed-Batch Cultivation Strategy for Efficient Oxytetracycline Production by Streptomyces rimosus at Semi-Industrial Scale. Braz Arch Biol Technol 58(5), 676-685 (2015).

44. Jain, R., Zaidi, K. U., Verma, Y. \& Saxena, P. L-Asparginase: a promosing enzyme for treatment of acute lymphoblastic leukemia. People's J Sci Res 5, 29-35 (2012).

45. Elsayed, E. A. et al. Bioprocess development for high cell mass and endospore production by Bacillus thuringiensis var israelensis in semi-Industrial Scale. J Pure Appl Microbiol 8, 2773-2783 (2014).

46. El-Naggar, N. E. \& Moawad, H. Streptomyces brollosae sp. nov., NEAE-115, A novel L-asparaginase producing actinomycete isolated from Brollos Lake at the Mediterranean Coast of Egypt. J Pure Appl Microbiol 9, 11-20 (2015a).

47. Saxena, R. K. \& Sinha, U. L-asparaginase and glutaminase activities in the culture filtrates of Aspergillus nidulans. Curr Sci 50, 218-219 (1981).

48. Wriston, J. \& Yellin, T. L-asparaginase: a review. Adv Enzymol Relat Areas Mol Biol 39, 185-248 (1973).

49. Plackett, R. L. \& Burman, J. P. The design of optimum multifactorial experiments. Biometrika 33, 305-325 (1946).

50. El-Naggar, N. E. Extracellular production of the oncolytic enzyme, L-asparaginase, by newly isolated Streptomyces sp. strain NEAE95 as potential microbial cell factories: Optimization of culture conditions using response surface methodology. Curr pharm biotechnol 16, 162-178 (2015b).

51. Lowry, O. H., Rosebrough, N. J., Farr, A. L. \& Randall, R. J. Protein measurement with the Folin phenol reagent. J Biol Chem 193, 265-275 (1951).

52. Dubois, M., Gilles, K., Hamilton, J. K., Rebers, P. A. \& Smith, F. Colorimetric method for determination of sugars and related substances. Anal Chem 28, 350-356 (1956).

\section{Acknowledgements}

The authors gratefully acknowledge the Science and Technology Development Fund (STDF), Egypt, for their financial support of this paper which is a part of the Grant No. 4943. The authors are very grateful to Prof. Mohamed Abdel-Fattah Farid in chemistry of natural and microbial products department in National Research Center for his help in setting up the bioreactor.

\section{Author Contributions}

N.E.E. proposed the research concept, providing necessary tools for experiments, designed the experiments, experimental instructions, performed the statistical analysis, analyzed and interpreted the data and contributed substantially to the writing and revising of the manuscript. H.M. contributed to the manuscript reviewing and had given final approval of the version to be published. N.M.E. and S.M.E. performed most of the experiments. I.E. participated in the bioreactor experiments. N.A.M.A. participated in the bioreactor experiments, contributed substantially to the writing of the manuscript and had given final approval of the version to be published. All authors read and approved the final manuscript.

\section{Additional Information}

Competing Interests: The authors declare no competing interests.

Publisher's note Springer Nature remains neutral with regard to jurisdictional claims in published maps and institutional affiliations.

(c) (i) Open Access This article is licensed under a Creative Commons Attribution 4.0 International License, which permits use, sharing, adaptation, distribution and reproduction in any medium or format, as long as you give appropriate credit to the original author(s) and the source, provide a link to the Creative Commons license, and indicate if changes were made. The images or other third party material in this article are included in the article's Creative Commons license, unless indicated otherwise in a credit line to the material. If material is not included in the article's Creative Commons license and your intended use is not permitted by statutory regulation or exceeds the permitted use, you will need to obtain permission directly from the copyright holder. To view a copy of this license, visit http://creativecommons.org/licenses/by/4.0/.

(c) The Author(s) 2019 